Linköping University Medical Dissertations

No. 1422

Molecular mechanisms in lymphoid restriction

-securing the $B$ lineage fate

\title{
Josefine Åhsberg
}

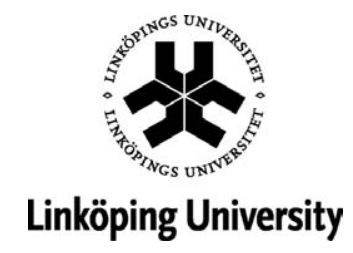

Department of Clinical and Experimental Medicine

Division of Experimental Hematology

Faculty of Health Sciences, SE-581 85 Linköping, Sweden

Linköping 2014 
(C) Josefine Åhsberg, 2014

Cover: hCD25 (mouse $\lambda 5$-reporter) positive cells in a paraffin embedded section of mouse bone marrow. Blue indicates DAPI, red indicates staining of hCD25. Sample preparation and image capture by Kristian Nihlberg.

Published articles have been reprinted with permission of the copyright holders:

Paper I (C) 2010 American Society for Biochemistry and Molecular Biology

Paper II (C) 2012 National Academy of Sciences

Paper III (C) 2011 American Society of Hematology

Paper IV (C) 2013 American Society for Biochemistry and Molecular Biology

ISBN: 978-91-7519-226-0

ISSN: 0345-0082

Printed in Sweden by LiU-Tryck, Linköping, Sweden, 2014. 
passion for science team work coffee 
Supervisor:

Mikael Sigvardsson

Department of Clinical and Experimental Medicine

Faculty of Health Sciences

Linköping University, Sweden

Co-supervisor:

Jan-Ingvar Jönsson

Department of Clinical and Experimental Medicine

Faculty of Health Sciences

Linköping University, Sweden

Faculty opponent:

Charles G. Mullighan

Department of Pathology

St. Jude Children's Research Hospital

Memphis, USA 


\section{$\underline{\text { ABSTRACT }}$}

With the work in this thesis I have aimed to deepen the understanding of the mechanisms behind the development of different blood cell lineages with a specific focus on B cell development.

To understand the interplay between extracellular signaling and transcription factor networks in early lymphoid development we investigated the functional collaborations of FLT3 and IL7R. We found that signaling via FLT3 and IL7R act in powerful synergy on proliferation of common lymphoid progenitors (CLPs). In addition to a role in expansion of progenitor cells we provided evidence for that IL7R signaling play a crucial role in B-cell commitment. IL7 deficient mice display a dramatic block in development before functional lineage restriction in the Ly6 $\mathrm{D}^{+}$CLP-compartment. The few Ly6 $\mathrm{D}^{+}$CLPs that do develop have reduced mRNA levels of transcription factor EBF1, a protein with crucial functions in lineage restriction and activation of the B-lymphoid program. One crucial function of EBF1 is to activate Pax5. Even though Pax5 deficient fetal liver cells upon transplantation to congenic hosts will generate an abundance of cells with an activated B-lineage transcriptional program, the pro-B cells have disrupted regulation of non-B-lineage transcripts and a propensity to develop into T- and NK-cells in vitro. Both the activation of the B-lineage program and lineage restriction was dependent on the dose of transcription factors. Mice carrying a heterozygous mutation for the transcription factor E2A had slightly reduced relative frequency of progenitor cells and an impaired B-lineage specification in CLPs. Loss of one allele of $E b f 1$ resulted in reduced surface expression of IL2R $\alpha$ and pre-B cell receptor (BCR), reduced IL7-response in vitro, and disrupted cell cycle dynamics in pro- and pre-B cells. While heterozygous loss of Pax5 did not result in any dramatic phenotype, the combined loss of one allele of Pax5 and one allele of Ebf1 $\left(\mathrm{Pax}^{+/} E b f 1^{+-}\right)$had a dramatic effect on lineage plasticity in B-cell progenitors compared to the single heterozygotes. Furthermore, these $\mathrm{Pax}^{+/-} \mathrm{Ebfl}^{+/-}$mice developed spontaneous, transplantable pro-B cell tumors and had a significantly reduced probability to survive over time. The transformed cells show high in vitro plasticity and tumor cells with induced overexpression of intracellular Notch1 can transform into T-lineage cell in vivo.

The data presented in this thesis add important pieces of information to the field of developmental hematopoiesis. By increasing the analytical depth of development in normal circumstances, and by understanding the consequence of genetic mutations in relation to cell type, we hope to contribute to the understanding of hematopoietic development in health and disease. 


\section{ACKNOWLEDGEMENTS/TACK TILL}

To my supervisor, Mikael Sigvardsson, who deserves the greatest thank you of all! Your enthusiasm and love for science is so inspiring. Thank you for always having a solution to problems big and small. Nothing is ever impossible! You have provided the best possible scientific environment one could ask for and it has been a pleasure working with you.

To Jan-Ingvar Jönsson, my co-supervisor, for always being around! Thank you for all the little tips and tricks, reagents, and general discussions over the years! I have really appreciated it.

Susanne, for being the one who sent a frustrated student who could not find a group for the masters project to floor 13 to talk to "that new professor who seemed to be a really nice guy". You were right, and the project was awesome.

Lotta and Pia, you are both such fantastic women and role models! It has been so comforting to have you around in the lab and you have been my every-day lunch companions at 11.30 sharp! Never hesitating to help, so full of knowledge and expertise you could probably run your own lab. :)

So many great people (and skilled scientists!) have come and gone in the Sigvardsson group: Hong, Panagiotis, Sasan, Jenny, Kristian, Eva, Robert, Jonas, Tobias, Cecilia. Thank you all for the good times, for everything that you taught me. I wish you all the best in life and with your careers, wherever they may take you! Also many thanks to the current group members: Lotta, Antara, Mahadesh and Sowmya. Also Rajesh, thank you for making it so easy for me to come back to work after parental leave, it is great working with you!

For all the wonderful people I have met over the years on "floor 13" I am truly grateful. Not all can be mentioned, but no one is forgotten. Work has never been work at all, but a home away from home, always someone to talk to about life and science. All is well if there is fredagsfika. Thank you Camilla (master of Canto-maintenance), Rada, Amanda, Tina, Emmy, Johanna, Pernilla for all the good times and the annual "kräftkalas". I'm looking forward to meet all the babies. :)

I am very grateful for the excellent flow cytometry core facility at Linköping University, and the knowledgeable staff, especially Florence. Thank you for always being patient and helpful and for keeping it together that time we missed to start the lasers... 
To the staff at the animal facility and especially to Linda for your willingness to learn as well as teach and for your invaluable help with our experiments.

Some people you just need. Thank you Helena, Josephine, Cecilia for being my friends.

To my dream team, Jonas and Tobias, for all the jokes, laughs and more or less sane discussions! For making the most tedious tasks fly by, for the team work, for the loving support and care when I was expecting my daughter! You are both greatly missed!

To my family, those who made me who I am: Mor, Far, Fredrik, Jon, Elin.

To Martin for all the support, good food and perfectly mixed gin\&tonics. Thank you for the late night dinner deliveries during long experiments and for taking care of home when I was away every odd hour of the day. Without you, this would have been so much harder. Tesla, although you can't read, I thank you, my canine companion and endless source of endorphins and unconditional love.

Så slutligen, min Majken, min ögonsten, min älskade.

Forever my love.

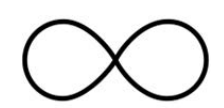





\section{TABLE OF CONTENTS}

PAPERS AND MANUSCRIPT INCLUDED IN THIS THESIS ……..................................

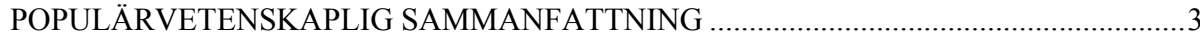

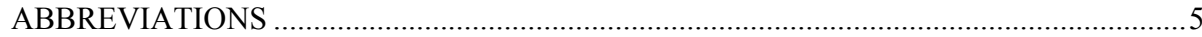

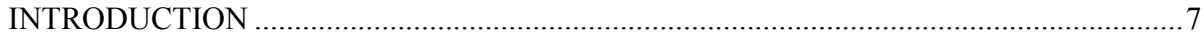

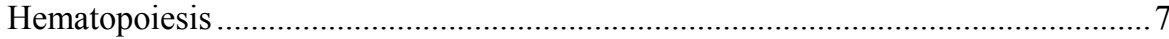

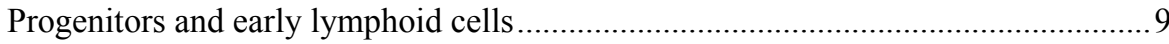

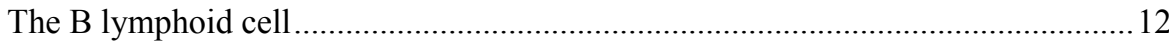

One genome - numerous cell types, the brilliance of gene regulation. …................ 14

Major transcription factors in B lymphoid development ........................................ 15

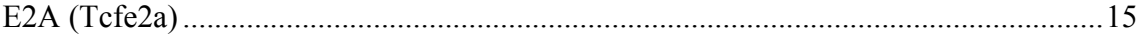

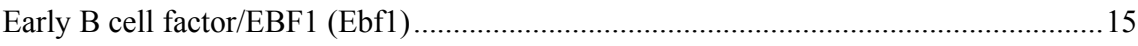

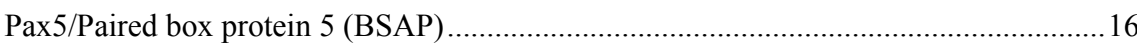

Networks regulating B cell development ............................................................ 17

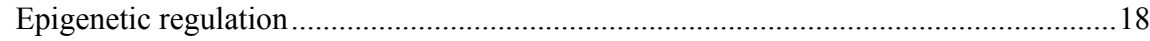

Priming the lymphoid lineage in early hematopoietic progenitors...................................19

Cytokine signaling, Flt3 and IL7R in B lymphoid development ....................................20

Transcription factor networks in early B lineage commitment ....................................21

The role of transcription factors and signaling molecules in lymphoid neoplasms.. 25

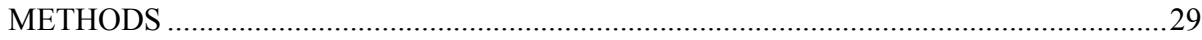

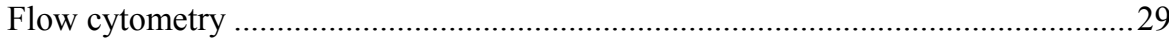

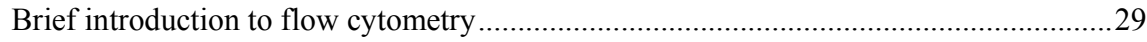

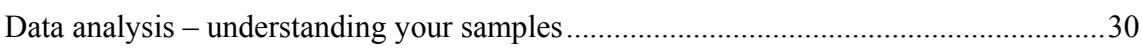

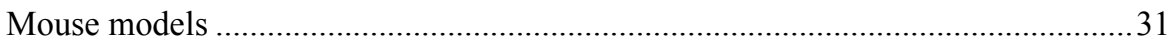

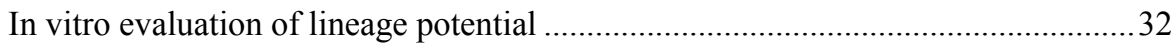

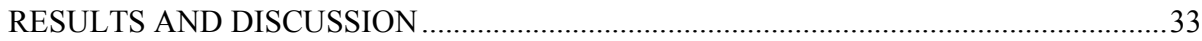

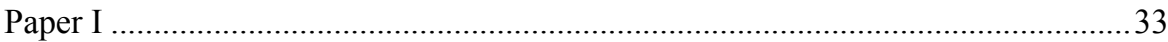

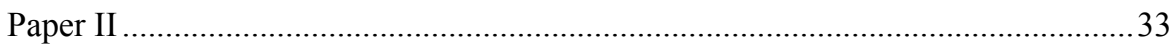

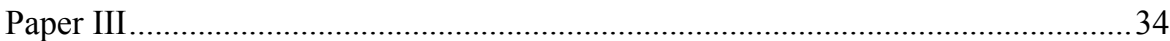

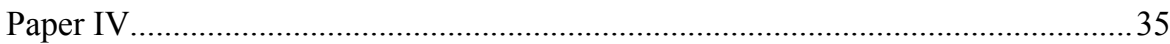

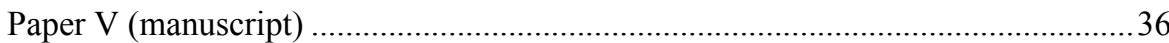

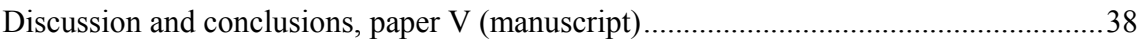

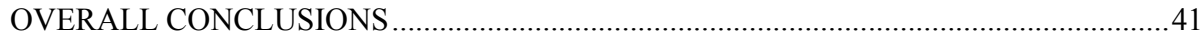

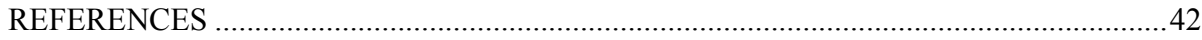





\section{PAPERS AND MANUSCRIPT INCLUDED IN THIS THESIS.}

I. Josefine Åhsberg, Panagiotis Tsapogas, Hong Qian, Jenny Zetterblad, Sasan Zandi, Robert Månsson, Jan-Ingvar Jönsson, Mikael Sigvardsson. Interleukin-7-induced Stat5 acts in synergy with Flt-3 signaling to stimulate expansion of hematopoietic progenitor cells.

Journal of Biological Chemistry 2010 Nov 19;285(47):36275-84

II. Panagiotis Tsapogas, Sasan Zandi, Josefine Åhsberg, Jenny Zetterblad, Eva Welinder, Jan-Ingvar Jönsson, Robert Månsson, Hong Qian, Mikael Sigvardsson. IL7 mediates Ebf-1-dependent lineage restriction in early lymphoid progenitors.

Blood 2011 Aug 4;118(5):1283-90

III. Sasan Zandi, Josefine Åhsberg, Panagiotis Tsapogas, Jenny Stjernberg, Hong Qian, Mikael Sigvardsson. Single-cell analysis of early B-lymphocyte development suggests independent regulation of lineage specification and commitment in vivo.

PNAS 2012 Sep 25;109(39):15871-6

IV. Josefine Åhsberg, Jonas Ungerbäck, Tobias Strid, Eva Welinder, Jenny Stjernberg, Malin Larsson, Hong Qian, Mikael Sigvardsson. Early B-cell factor 1 regulates the expansion of B-cell progenitors in a dose-dependent manner.

Journal of Biological Chemistry 2013 Nov 15;288(46):33449-61

V. Jonas Ungerbäck ${ }^{*}$, Josefine Åhsberg ${ }^{*}$, Rajesh Somasundaram, Tobias Strid, Henrik Lilljebjörn, Thoas Fioretos and Mikael Sigvardsson. Combined heterozygote loss of Pax5 and Ebf1 in early B-cell development cause lineage instability and promote development of pro-B cell leukemia. ${ }^{*}$ authors contributed equally

Manuscript submitted to Cancer Cell

Throughout the text, each paper will be referred to by its roman numeral. 
Published work performed during my doctorate that is not included in this thesis.

Eva Welinder, Josefine Åhsberg, Mikael Sigvardsson. B-lymphocyte commitment: identifying the point of no return.

Seminars in Immunology. 2011 Oct;23(5):335-40

Robert Månsson, Eva Welinder, Josefine Åhsberg, Lin YC, Benner C, Glass CK, Lucas JS, Mikael Sigvardsson, Cornelis Murre. Positive intergenic feedback circuitry, involving EBF1 and FOXO1, orchestrates B-cell fate.

PNAS 2012 Dec 18;109(51):21028-33 


\section{POPULÄRVETENSKAPLIG SAMMANFATTNING}

En stamcell har den unika egenskapen att den kan bilda en exakt kopia av sig själv vid celldelning, samtidigt som den har förmågan att vidareutvecklas till olika celltyper. Kroppens vävnader har sina egna stamceller, exempel på vävnader kan vara hud, tarm och blodbildande organ. De stamceller som vid cell-delning ger upphov till blodets olika celltyper finns i benmärgen. När blod-stamcellen delar sig bildas en typ av "förstadie-celler" och beroende på bland annat vilka signaler dessa förstadie-celler sedan kommer i kontakt med så kan de via specifika utvecklingsstadier bilda alla typer av blodceller. Vi har studerat dessa förstadieceller, med ändamålet att förstå vilka signaler som är viktiga för det normala bildandet av Bceller. B-celler är en typ av vita blodkroppar som tillsammans med ett flertal andra specifika celltyper bygger upp vårt immunsystem. När en B-cell träffar på främmande ämnen i kroppen, till exempel virus eller bakterier, så upptäcker B-cellen dessa via antikroppar (en slags signalmottagare) som sitter på B-cellens yta. Det främmande ämnet kan då förstöras av andra blodceller som har andra specifika egenskaper.

I arbete I studerades en omogen blodcell som kallas CLP. Man kan sortera ut denna celltyp baserat på att den bland annat har två speciella mottagarmolekyler på ytan, dessa heter FLT3 och IL7R. Vi kunde konstatera att den samtida aktiveringen av båda dessa mottagare var väldigt viktigt för att CLP-cellerna snabbt skulle kunna delas och ge upphov till många nya CLP-celler. I arbete II ville vi veta vad som hände med blodcellerna om de kom från en mus som på grund av en genetisk förändring saknade IL7, den faktor som aktiverar IL7R. Dessa möss saknar bland annat B-celler. I normala möss är CLP uppdelade i två grupper, en mindre mogen cell som saknar Ly6D på cellytan, och en mer mogen som har Ly6D på cellytan. Vi kunde fastställa att CLP-celler från möss utan IL7 uttryckte väldigt lite Ly6D, och att de få Ly6D-uttryckande cellerna som fanns hade förändrade egenskaper.

I arbete III studerade vi en annan genetiskt förändrad mus vars celler saknar proteinet Pax5, vilket är välkänt viktigt för utvecklingen av B celler. Vi kunde dock visa att även i de förstadie-celler som saknade Pax5 så gick det att mäta uttrycket av gener som är specifika för B-celler. Vi drog därför slutsatsen att Pax5 är viktig för att bibehålla det genetiska B cellsprogrammet. Med arbete IV började vi studera hur dosen av olika faktorer påverkar cellerna. Förutom Pax5 studerade vi bland annat även ett annat viktigt B-cellsprotein som heter EBF1. Det visade sig att om man ungefärligen halverade mängden av ett eller båda dessa proteiner så gav det upphov till olika grad av minskade cellantal, men framförallt så påverkade det cellernas funktion och deras benägenhet att "byta" utvecklingsriktning mot andra typer av vita blodkroppar. I arbete $\mathbf{V}$ har vi arbetat vidare med mössen som uttrycker 
låga doser av Pax5 och EBF1 och ytterligare studerat deras förmåga att bilda olika typer av celler. Genom att jämföra möss som bara har halv dos av antingen Pax5, EBF1 eller båda samtidigt (Pax5/EBF1) har vi upptäckt att Pax5/EBF1 mössen vid ungefär 30 veckors ålder utvecklat aggressiva blodcellstumörer (leukemier) av B-cellstyp. Förändringar i generna för Pax5 och EBF1 förekommer i stor utsträckning även i mänskliga leukemier, och vi vill med fortsatt forskning förstå den underliggande mekanismen till varför dosen av dessa faktorer är så viktiga för stabiliteten i utvecklingen från stamcell till färdig B-cell. 


\section{ABBREVIATIONS}

ALL acute lymphoblastic leukemia

Bcl2 b-cell leukemia/lymphoma 2

BCR b-cell receptor

BM bone marrow

CD cluster of differentiation

CLP common lymphoid progenitor

Cre cre recombinase (causes recombination)

DC dendritic cell

E2A transcription factor E2A (Tcfe2a)

EBF1 early B-cell factor 1

ER estrogen receptor

FACS fluorescence activated cell sorting

FL fetal liver

Flt3 fms-like tyrosine kinase 3

Flt3L fms-like tyrosine kinase 3 ligand

FOXO1 forkhead box protein $\mathrm{O} 1$

HSC hematopoietic stem cell

ICN constitutively active Notch 1

ID inhibitor of DNA binding

IgH immunoglobulin heavy chain

IgL immunoglobulin light chain

IKAROS ikaros family zinc finger 1 (Ikzfl)

IL7 interleukin 7

IL7R interleukin 7 receptor

Kit Kit oncogene

Lin $^{-} \quad$ lineage surface marker negative

LMPP lymphoid primed multipotent progenitor

LSK $\quad$ lin $^{-} \mathrm{Scal}^{+} \mathrm{Kit}^{+}$

Ly6D lymphocyte antigen 6 complex, locus D

MPP multipotent progenitor

NK natural killer cell

PAX5 paired box gene 5

Pre-B $\quad \operatorname{lin}^{-} \mathrm{B} 220^{+} \mathrm{CD} 19^{+} \mathrm{CD} 4{ }^{\text {low } /}{ }^{-} \mathrm{IgM}^{-}$ 


\author{
Pro-B $\quad$ lin $^{-} \mathrm{B} 220^{+} \mathrm{CD} 19^{+} \mathrm{CD} 43^{\text {high }} \mathrm{IgM}^{-}$ \\ $\operatorname{Rag} 1 / 2$ recombination activating gene $1 / 2$ \\ Sca1 stem cell antigen 1 (Ly6a) \\ SLC surrogate light chain \\ STAT5 signal transducer and activator of transcription 5 \\ TF transcription factor \\ TH transheterozygote $\left(\mathrm{Pax5}^{+/-} \mathrm{Ebfl}^{+/-}\right)$ \\ Wt wild type \\ ZNF432 zink finger protein 432 \\ ZNF521 zink finger protein 521
}


INTRODUCTION

\section{Hematopoiesis}

When searching for hematopoiesis in any dictionary, you will find the meaning of this word to be basically "the making of blood or blood cells in the living body". This is a quite adequate explanation of the term. However, when giving it some further thought, it becomes clear that hematopoiesis is in fact an immensely complex process. In order for the right cells to develop at the correct time, expression of key genes, activation and/or deactivation of signaling pathways and action of transcription factors (TF) need to be precisely and timely controlled. If this fails and a cell develops incorrectly, in most cases this will result in cell death. However, in the event of an unfortunate combination of errors, development can go awry, and lead to for instance the development of leukemia or other blood cell diseases.

During fetal development, early hematopoiesis takes place in the extra-embryonic yolk sac (Moore and Metcalf, 1970; Palis and Yoder, 2001), placenta (Gekas et al., 2005; Mikkola et al., 2005) and intra-embryonic aorta-gonad-mesonephros (AGM) region (Medvinsky and Dzierzak, 1996). From about embryonic day 9 (E9) hematopoietic stem cells are found in the liver (Medvinsky and Dzierzak, 1996; Muller et al., 1994), and the liver remains the major site for hematopoiesis until the time of birth after which hematopoiesis takes place in the bone marrow (BM) (Mikkola and Orkin, 2006). An estimated number of six billion $\left(10^{9}\right)$ cells per kilogram of body weight are produced each day (Marshall A. Lichtman, 2010) supporting our bodies by distributing oxygen, maintaining vascular integrity, and building our immune systems to fight of disease. Each cell type created has a specific function and cells will also communicate with each other and their surroundings to perform their tasks.

The founders of the entire hematopoietic system are the hematopoietic stem cells (HSC). These cells reside in the BM and will by asymmetric division give rise to new stem cells as well as multipotent progenitor cells. These will branch out in a developmental hierarchy of more or less lineage restricted progenitors and through series of steps and complex interactions between intracellular and extracellular factors become mature, functional blood cells. Our understanding of how this developmental hierarchy is structured is under constant revision, with new scientific techniques and new surface markers adding to the emerging picture. Even though the basic understanding of the developmental pathways in hematopoiesis has been rather well understood for the last 15-20 years, higher resolution analysis has allowed for a better understanding for the underlying molecular events that regulate blood cell differentiation. 


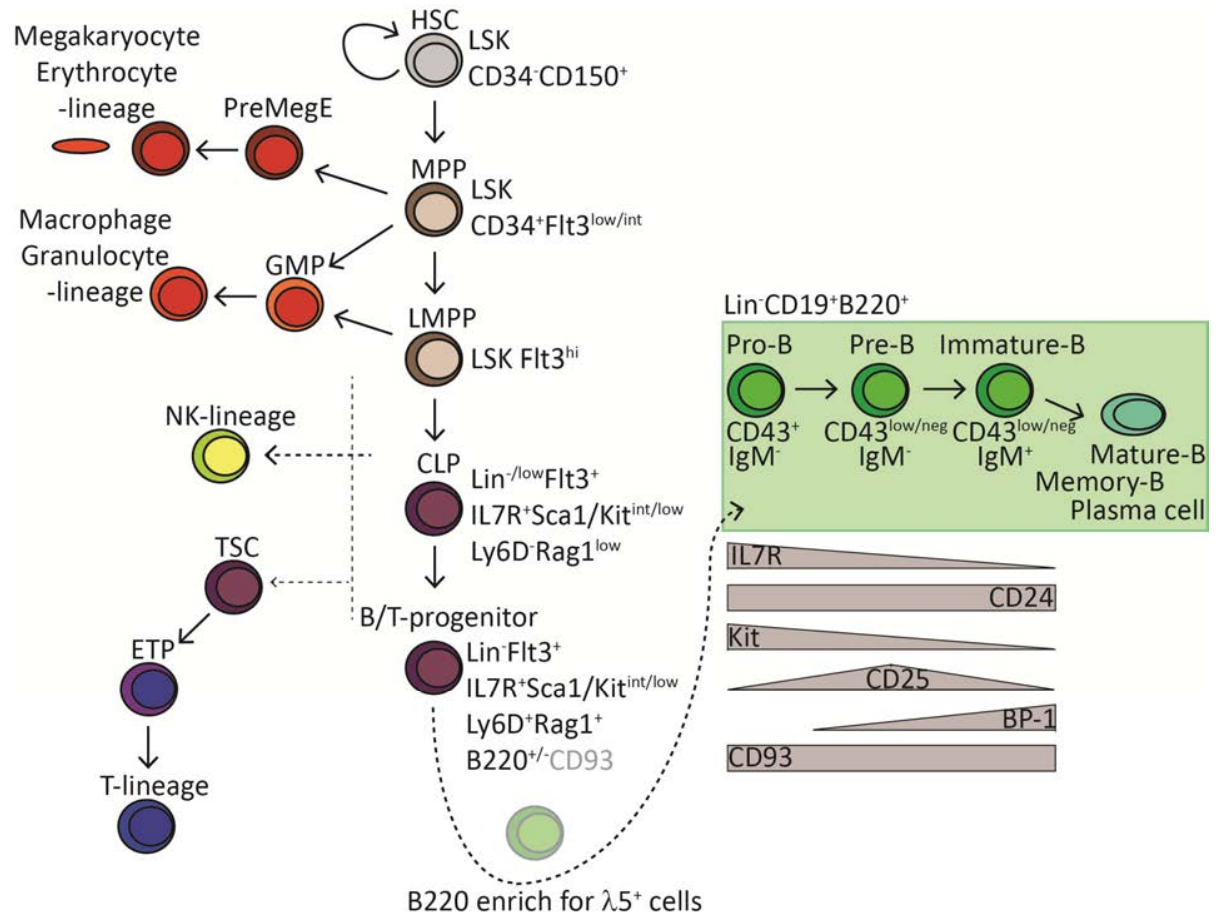

Figure 1. Schematic drawing of the hematopoietic developmental hierarchy based on surface markers. Essential surface markers are indicated and developmental pathways are pointed out by arrows. Dashed lines indicate ambiguous pathways. Lin-: B220, CD19, Ter119, CD3, Gr1, Mac1/CD11b, CD11c, NK1.1, LSK; Lin ${ }^{\text {low/- Sca1 }}{ }^{+}$Kit $^{+}$, HSC: hematopoietic stem cell, PreMegE: megakaryocyte erythrocyte progenitor, MPP: multipotent progenitor, GMP: granulocyte monocyte progenitor, LMPP: lymphoid primed multipotent progenitor, CLP: common lymphoid progenitor, NK: natural killer, TSC: thymus seeding cell, ETP: early thymic progenitor, Rag1: cells positive for Rag1 regulated GFP expression (Mansson et al., 2009), $\lambda 5^{+}$: cells positive for the hCD25- $\lambda 5$ transgene (Mansson et al., 2008; Martensson et al., 1997). CD24 (HSA), CD25 (IL2R $\alpha$ ), CD93 (AA4.1). 


\section{Progenitors and early lymphoid cells}

Even though the most accurate way to define a truly functional HSC is to show that it has the ability to self-renew and to repopulate all hematopoietic lineages upon transplantation to a new host, well established surface marker expression can allow for a dramatic enrichment of stem cells from the BM.

A current view of the developmental hierarchy from HSC to B cell is depicted in figure 1, with brief descriptions of central surface markers in Box 1. The HSC can give rise to all blood cell lineages over the life time of a mouse given the right conditions. The cell type can be isolated from mouse BM based on being negative for markers expressed on lineage restricted progenitors and mature blood cells (lineage negative/lin') while being positive for CD150 (Slamf1) and having high expression of Scal and Kit (Kiel et al., 2005; Papathanasiou et al., 2009). A subsequent $\mathrm{CD} 34^{+}$Flt $3^{\text {low/int }}$ stage represents the multipotent progenitors (MPPs) (Adolfsson et al., 2005; Osawa et al., 1996). The MPP is a heterogeneous population that has lost long term repopulation ability, but that can become any cell type within the hematopoietic system. From the MPP stage, cells of megakaryocyte/erythrocyte lineage, resulting in the oxygen carrying erythrocytes (red blood cells) and the blood clotting thrombocytes (platelets) will emerge. Also the macrophage/granulocyte lineages, responsible for killing and removal of pathogens and dead cells, diverge from this heterogeneous population. By separating out only the highest Flt3 expressing cells in the MPP population, a separate population called the lymphoid primed multipotent progenitors (LMPPs) can be identified (Adolfsson et al., 2005). The LMPPs still retain the ability to repopulate most lineages, but have a limited ability to become erythrocytes or thrombocytes (Adolfsson et al., 2001; Forsberg et al., 2006).

The next step in development towards B lineage cells is the differentiation of the LMPP into the common lymphoid progenitor, the CLP. This population was initially defined as a Lin ${ }^{-} I L 7 \mathrm{R}^{+}$Thy $1.1^{-} \mathrm{Sca} 1^{\text {low }} \mathrm{Kit}^{\text {low }} \mathrm{BM}$ cell with the ability to become $\mathrm{B}, \mathrm{T}$ and natural killer (NK) cells (Kondo et al., 1997b). This population was found to express Flt3, resulting in the inclusion of this surface marker in the CLP definition (Karsunky et al., 2008). Since these initial findings, the definition of the CLP has been revised. One major breakthrough was the discovery that this population was heterogeneous with regard to the expression of recombination activating gene (Rag) 1 and Ly6D (Inlay et al., 2009; Mansson et al., 2009) and that there was a significant overlap between surface expression of Ly6D and expression of Rag1. This expression turned out to be a clear breaking point for the ability of CLPs to give rise to NK cells, and the progenitors responsible for the production of NK cells branch 
out somewhere before the expression of Ly6D. Detection of expression of the B lineage restricted gene lambda $5(\lambda 5 /$ Igll1), part of the pre-BCR surrogate light chain, is possible by cell surface staining of human(h)CD25, in the hCD25- $\lambda 5$ reporter mouse (Martensson et al., 1997). By analyzing mice with both the hCD25- $\lambda 5$ reporter and the Rag1-GFP reporter it was found that a subpopulation of $\operatorname{Rag} 1^{+}$CLPs expressed the hCD25- $\lambda 5$ reporter, indicative of Blineage commitment (Mansson et al., 2009).

For the generation of T-lineage cells, it is believed that an early progenitor will leave the $\mathrm{BM}$ as a thymus seeding cell (TSC) and via circulation migrate to the thymus where activation of the $\mathrm{T}$ cell program by interaction with Notch ligands in the thymic micro environment promote T cell development. Studies have shown that the TSC likely is found in a LSK Flt $3^{+}$population and thymic LSK Flt $3^{+}$cells had $\mathrm{T}$, myeloid as well as B-lineage potential, and the latter was lost in the Flt3- thymic LSKs (Luc et al., 2012; Sambandam et al., 2005). Although Ly6 $\mathrm{D}^{+} \mathrm{CLPs}$, or B-cell-biased lymphoid progenitors (BLPs), were shown to have remaining T lineage potential in vivo and in vitro (Inlay et al., 2009; Mansson et al., 2009), CLPs are not detected in peripheral blood (Schwarz and Bhandoola, 2004) and BLPs do not migrate to thymus after intravenous transplantation (Inlay et al., 2009). Upon arrival of the TSC to the thymus, exposure to Notch ligands in the thymic stroma can activate the Notch pathway. This results in down regulation of Flt3 and up regulation of CD25 (IL2R $\alpha$ ), possibly forming the early thymic progenitor (ETP) (Bell and Bhandoola, 2008; Sambandam et al., 2005; Wilson et al., 2001).

Between the developmental stages of lymphoid restricted progenitor and committed B lineage lies the previously defined FractionA(Fr.A)/Pre-Pro-B cell (Hardy et al., 1991; Li et al., 1993). This population was presented as $\mathrm{B} 220^{+} \mathrm{CD} 43^{+} \mathrm{BP} \cdot 1^{-} \mathrm{CD} 24^{-}$cells with germline Ig rearrangement and proposed to be the first B-lineage committed cell ( $\mathrm{Li}$ et al., 1996). However, investigations increasing the resolution of the analysis of this population have shown that it is a much heterogeneous population. Widely used B220 is indeed present on most $\mathrm{CD} 19^{+}$cells, but is demonstrated to be expressed also in $\mathrm{CD}^{-} 9^{-}$progenitors, including cells with retained in vitro T-cell (Rumfelt et al., 2006) and even NK-cell potential (Rolink et al., 1996). Further, B-lineage commitment was seen in cells double negative for both B220 and CD19 (Mansson et al., 2008) suggesting that B220 is not an ideal marker for early committed B-cell progenitors. In addition, the expression of CD24 detected on most CD19 ${ }^{+}$ cells (Rumfelt et al., 2006), is not useful in the analysis when CD19 is not included as a part of the B-lineage definition. Also the later adopted surface marker CD93 (AA41) has been shown to be expressed within both progenitor and B-committed populations. Two detailed 
studies from separate groups showed that B220 was the only surface marker separating the Ly6D ${ }^{+}$CLPs from the FrA/Pre-Pro-B cells, with B220 simply enriching for B lineage biased cells (Mansson et al., 2009; Rumfelt et al., 2006). These data are much in line with early studies that indeed demonstrated NK-progenitor potential in a $\mathrm{B} 220^{+} \mathrm{CD} 19^{-} \mathrm{BM}$ population (Rolink et al., 1996). Hence, further research to find a surface marker able to distinguish the transition from B-lineage biased progenitors to B-lineage committed cells is needed, as it is not currently possible without transgenic reporter mice.

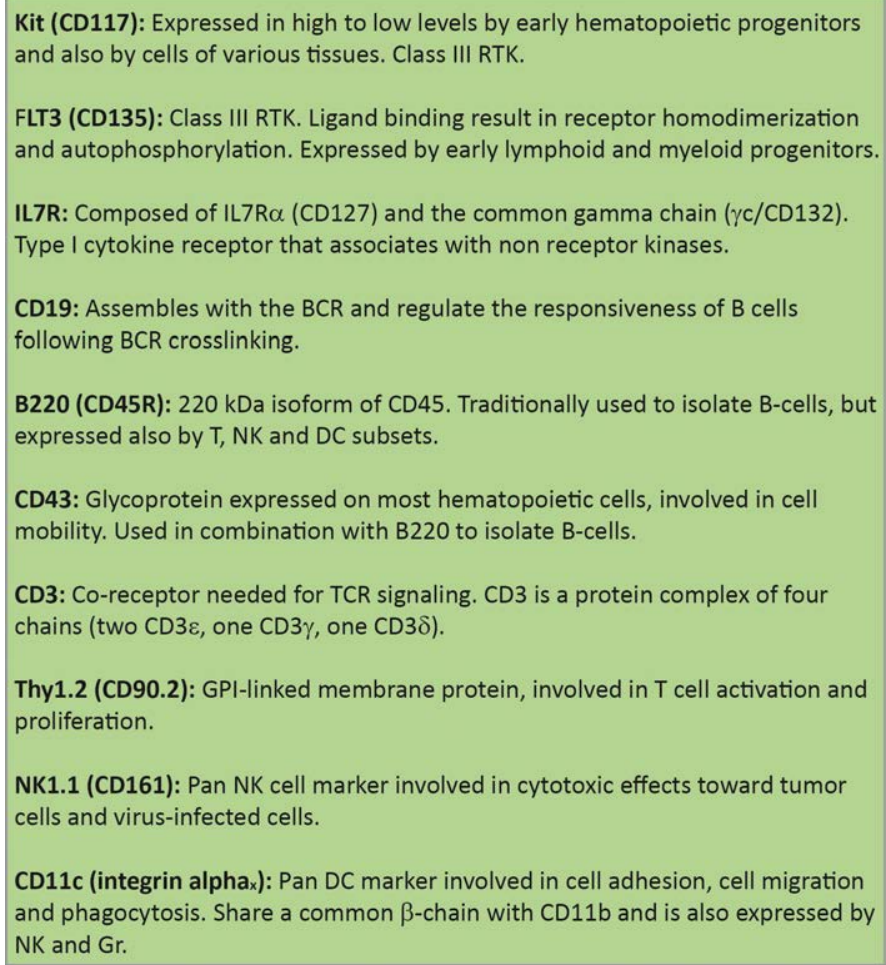

Thy1.2 (CD90.2): GPI-linked membrane protein, involved in T cell activation and proliferation.

NK1.1 (CD161): Pan NK cell marker involved in cytotoxic effects toward tumor cells and virus-infected cells.

CD11c (integrin alphax): Pan DC marker involved in cell adhesion, cell migration and phagocytosis. Share a common $\beta$-chain with $\mathrm{CD} 11 \mathrm{~b}$ and is also expressed by NK and Gr.

Box 1. Brief descriptions of central surface markers for both in vivo and in vitro studies performed within the scope of this thesis. RTK: receptor tyrosine kinase, BCR: B-cell receptor, NK: natural killer, DC: dendritic cell, TCR: T-cell receptor, GPI: Glycerophosphatidylinositol, Gr: granulocyte 


\section{The B lymphoid cell}

After committing to B lineage development in a CD19 negative progenitor, presented in figure 1 as a Lin ${ }^{-} \mathrm{Flt} 3^{+} \mathrm{IL} 7 \mathrm{R}^{+} \mathrm{Sca} 1 / \mathrm{Kit}^{\text {int/low }}{ }^{\mathrm{Ly}} 6 \mathrm{D}^{+} \mathrm{Rag} 1^{+}$cell, further differentiation is required to generate the mature $\mathrm{B}$ cell, expressing an antigen specific $\mathrm{B}$ cell receptor (BCR). To enable the expression of a functional BCR, a process called V(D)J-recombination, which is the rearrangement of variable (V), diversity $(\mathrm{D})$ and joining $(\mathrm{J})$ regions of the $\mu$-heavy $(\mathrm{H})$ chain $(\mu \mathrm{HC})$ gene, needs to be initiated by RAG1 and RAG2 protein complexes (Oettinger et al., 1990; Schatz et al., 1989). Expression of Ragl is detected already in the early non committed progenitors (Igarashi et al., 2002) and the expression increases throughout the LMPP to CLP transitions (Mansson et al., 2008). The first signs of functional Rag-recombinase activity in B-lineage progenitors are $\mathrm{D}_{\mathrm{H}^{-}} \mathrm{J}_{\mathrm{H}}$ rearrangements seen in the CLP stage (Borghesi et al., 2004; Rumfelt et al., 2006). Subsequent differentiation involves expression of Pax 5 that will initiate $\mathrm{CD} 19$ expression resulting in a $\mathrm{CD} 19^{+} \mathrm{B} 220^{+} \mathrm{CD} 43^{+}$pro-B cell.

After completed $\mathrm{D}_{\mathrm{H}^{-}} \mathrm{J}_{\mathrm{H}}$ rearrangement (on both alleles) followed by $\mathrm{V}_{\mathrm{H}^{-}}-\mathrm{DJ}_{\mathrm{H}}$ recombination the cell becomes a large pre-B cell, characterized by reduced expression levels of CD43 and expression of a pre-BCR (figure2). This pre-BCR is constructed by the newly rearranged $\mu \mathrm{HC}$ in combination with surrogate light chain (SLC) proteins lambda5 ( $\lambda 5$ ) and VpreB. Signaling via pre-BCR will down regulate Rag1 and Rag2 gene expression, thereby preventing further $\mathrm{V}_{\mathrm{H}}-\mathrm{DJ}_{\mathrm{H}}$ rearrangement (Grawunder et al., 1995), promoting a homogenous expression of a single type of heavy chain in any given B-cell. Several rounds of cell division will expand pre-B populations with functional pre-BCR. The pre-BCR also appears to promote clonal deletion of auto reactive specificities because mice lacking functional SLC develop increased levels of antinuclear antibodies (Keenan et al., 2008). Even though the pre$\mathrm{BCR}$ on the cell surface is not easily detected on B-cell progenitors, mice lacking a functional transmembrane region in the constant part of IgM do not develop into the CD25 $5^{+}$stage thought to represent progenitors that has received a functional pre-BCR signal (paperIV, (Rolink et al., 1994). Studies show that signaling through the pre-BCR in combination with IL7R will expand a pool of large pre-B cells that have successfully rearranged a functional immunoglobulin heavy chain (Erlandsson et al., 2005; Fleming and Paige, 2001). Further, pre-BCR signaling will induce silencing of surrogate light chain gene expression (Parker et al., 2005) and promote the initiation of recombination of the $\operatorname{IgL}$ (light) $\left(\mathrm{V}_{\mathrm{L}}-\mathrm{J}_{\mathrm{L}}\right)$ gene (Reth et al., 1987). After functional IgL recombination, the heavy and light chain will assemble into a complete BCR of initially IgM and, after negative selection in the BM, IgD isotype. Combined surface expression of $\operatorname{IgM}$ and $\operatorname{IgD}$ has been suggested to indicate that the B-cell is mature, and exposure to antigens and interaction with $\mathrm{T}$ cells in the germinal centers will 
allow for the functional induction of an immune response and isotype switch, where activation induced cytidine deaminase (AID) initiated class switching will produce other isotypes of $\operatorname{IgG}$, IgE or IgA class as well as somatic hypermutation.

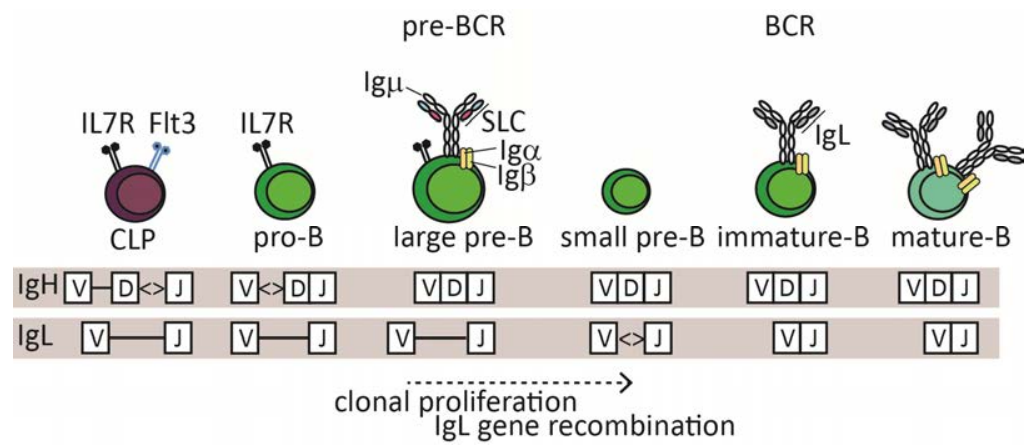

Figure 2. Rearrangement of Immunoglobulin genes and expression of B-cell receptor. SLC: surrogate light chains, IgH: heavy chain immunoglobulin gene, IgL: light chain immunoglobulin gene, V: variable, D: diversity, J: joining. 


\section{One genome - numerous cell types, the brilliance of gene regulation.}

With very few exceptions all the cells in the body of any given organism contain the same genetic material. Despite this there are fundamental differences in how different cell types look and behave such as neurons in the brain, skin cells and blood cells. This variation is possible due to regulated use of the genetic material, in the way that different types of cells have different sets of activated and silenced genes. About $10 \%$ of the human genes are expected to be coding for transcription factors (TFs) (Levine and Tjian, 2003), which form regulatory networks that control the stepwise process of development from for example a HSC to a mature blood cell. In a cell type or developmental stage, TFs can bind in different patterns and co-localize in different complexes (Prange et al., 2014), creating a range of regulatory possibilities. External signaling via surface receptors such as IL7R and Flt3 make the cell responsive to its surrounding milieu, further increasing the complexity. Activation of signaling cascades by surface receptors can regulate TF expression and activity, and active TFs can in turn modulate surface expression of receptors. Which genes that are activated within the cells and which developmental direction the cells take depend on interplay between different factors such as:

- Epigenetic modifications increasing or decreasing accessibility and expression of genes.

- Extracellular activation of signaling cascades though cell surface receptors.

- Activation of intracellular transcription factors acting to activate or repress genes.

For the development of B cells, a few central TFs are responsible for the determination of the B cell fate, and below follow a brief description of these TFs that are also a central topic covered by the work in this thesis. 


\section{Major transcription factors in B lymphoid development}

\section{E2A (Tcfe2a)}

Transcription factor E2A (figure 3) is a class I bHLH (basic helix-loop-helix) protein that belongs to the E-family and is encoded by the $T c f e 2 a$ gene which by differential splicing utilizing two different bHLH encoding exons to produce two isoforms, named E12 and E47 (Murre et al., 1989; Sun and Baltimore, 1991). The helix-loop-helix domain mediates dimerization of E-proteins and the basic region mediates binding to DNA. E-family proteins, including HEB and E2-2 bind to the E-box motif, CANNTG (N = any nucleotide), which was initially identified in the mouse IgH intron enhancer (Ephrussi et al., 1985). E-proteins have varying degrees of impact on hematopoietic development, and while both HEB and E2-2 are involved in B cell development (Welinder et al., 2011; Zhuang et al., 1996), E2A has been shown to play a critical role in in the B lineage developmental progression (Bain et al., 1994; Bain et al., 1997; Beck et al., 2009; Zhuang et al., 1994). E-proteins are post translationally regulated both by protein modifications (Benezra, 1994; Shen and Kadesch, 1995; Sloan et al., 1996; Teachenor et al., 2012) and by the presence of ID (inhibitor of differentiation)proteins. ID's are HLH proteins lacking the basic domain, which antagonize binding to DNA by E-proteins coupled to ID (Benezra et al., 1990). The E-proteins are expressed throughout many tissues and in different stages of development, and their tissue specific function lies in the homo- or hetero-dimerization pattern of the proteins. One example is the formation of heterodimers between E2A and bHLH protein MyoD in myogenesis (muscle development) (Berkes and Tapscott, 2005; Lassar et al., 1991). B cell development in contrast is apparently dependent on E-protein homodimers, specifically E47 (Shen and Kadesch, 1995) and homodimers have been shown to possess high functional activity in the activation of Blineage genes (Sigvardsson, 2000).

\section{Early B cell factor/EBF1 (Ebfl)}

EBF1 (figure 3) was initially identified as a factor that regulated the expression of the Blineage gene CD79a (Ig $\alpha / m b-1)$ (Feldhaus et al., 1992; Hagman et al., 1991). The DNA binding domain of EBF-proteins has a unique zinc coordination motif called the "zinc knuckle" where four amino acids (H157, C161, C164 and C170) are essential for DNA binding. These amino acids are organized in a loop, stabilized around the simultaneous binding of a zinc ion $\left(\mathrm{Zn}^{2+}\right)$ (Fields et al., 2008; Hagman et al., 1995). EBF1-molecules are thought to bind to DNA as dimers by interacting with two pseudo-palindromic half sites separated by a 2 base pair spacer, ATTCCCNNGGGAAT, where NN can be any nucleotide 
(Hagman et al., 1991; Travis et al., 1993). The crystal structure of the different domains of EBF1, and also of the DNA-binding domain (DBD, amino acids 26-240) bound to DNA was determined by two groups in 2010 (Siponen et al., 2010; Treiber et al., 2010). Besides its expression in hematopoietic development, EBF1 has a role in adipocyte differentiation (Akerblad et al., 2002) neuron and brain development (Garel et al., 1999; Wang and Reed, 1993) and osteoblast development (Hesslein et al., 2009).

\section{Pax5/Paired box protein 5 (BSAP)}

PAX5 (also called B-cell-specific activator protein, BSAP) was early on shown to be a regulator of the CD19 gene (Kozmik et al., 1992). Pax5 binds to DNA via its N-terminal DBD called the paired domain (Czerny et al., 1993). This paired domain is well conserved through evolution and consists of two sub-domains that independently can bind to half sites in the recognition sequence. This type of binding allows for the highly variable Pax5consensus site, with varying affinity for either of the half sites (Garvie et al., 2001; Xu et al., 1995). The partial homeodomain is a general DNA-binding motif involved in protein-protein interactions (Eberhard and Busslinger, 1999) and the octapeptide modulate the transcriptional activity (Lechner and Dressler, 1996). Pax proteins in general are widely expressed in many tissues, and besides being the only Pax-protein important for B lymphocytes, Pax 5 is also important for development of the central nervous system (Blake and Ziman, 2014; Urbanek et al., 1994).
consensus binding site
a) $E 2 A$
\begin{tabular}{|l||l|}
\hline TA & TA \\
\hline
\end{tabular}
$\mathrm{b} \mid \mathrm{HLH}$
CANNTG
b) EBF1 \begin{tabular}{|l|l|l|l|l|l}
\hline $\mathrm{Zn}$ & $\mathrm{HLHLH}$ & $\mathrm{TA}$ & $\mathrm{TCCCNNGGGA}$ \\
\hline
\end{tabular}

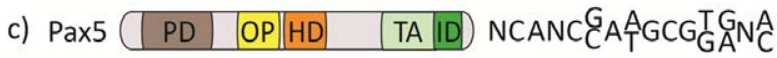

Figure 3. A schematic view of three major transcription factors in B cell development. a) basic domain (b) is needed for binding to E-boxes and the helix-loop-helix (HLH) region mediates protein dimerization b) A unique zinc-finger (Zn) coordinates DNA-binding and the HLHLH domain is responsible for protein dimerization c) The paired domain (PD) mediates DNA binding and the octapeptide motif (OP) is involved in gene activation and repression. The homeodomain (HD) is involved in protein interactions and the inhibitory domain (ID) regulates transcription. The transactivation domain (TA) in a-c regulates transcription. 


\section{Networks regulating B cell development}

In the mid 1990's studies on several different mouse models deficient for varying transcription factors and signaling molecules were created. Mice deficient in Sox4 (Schilham et al., 1996), Pax5 (Urbanek et al., 1994), Ebf1 (Lin and Grosschedl, 1995), E2A (Bain et al., 1994; Zhuang et al., 1994), IKAROS (Georgopoulos et al., 1994; Wang et al., 1996), PU.1 (McKercher et al., 1996; Scott et al., 1994) and IL7 (von Freeden-Jeffry et al., 1995) all lacked early B cells, revealing that these proteins are necessary for the development of a fully functional hematopoietic system (figure 4).

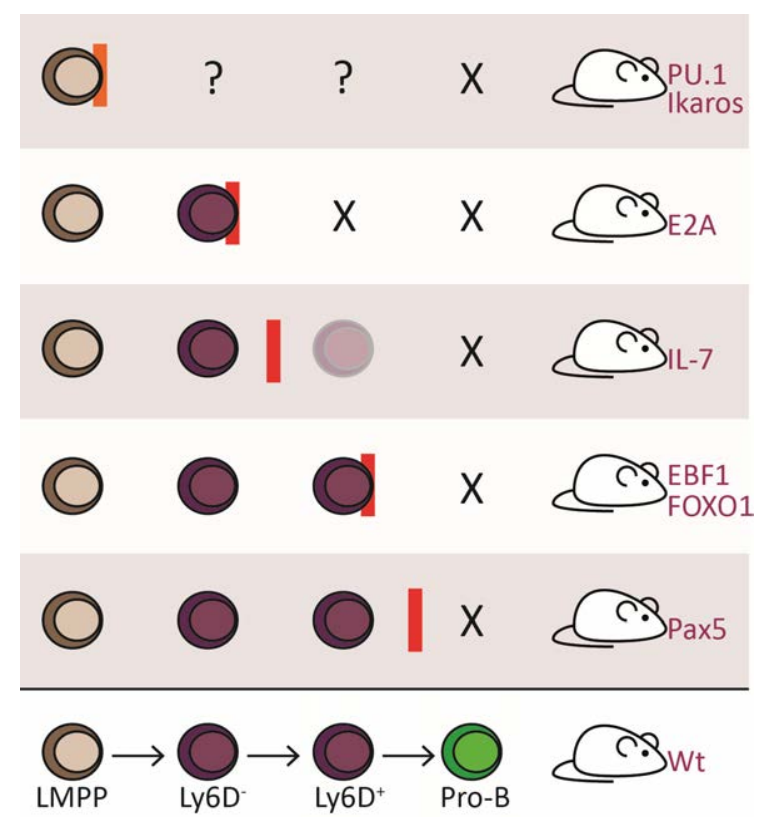

Figure 4: Phenotypic outcome in gene deficient mice. Displayed is a schematic drawing of seven different gene deficient mice, wild type mice are shown on bottom as reference. Red rectangle marks major block in development, orange rectangle marks indicative developmental block, $\mathrm{X}$ marks major reductions in cell populations in vivo. References: PU.1(McKercher et al., 1996; Scott et al., 1994), IKAROS(Georgopoulos et al., 1994; Wang et al., 1996), E2A(Dias et al., 2008; Inlay et al., 2009), IL7 (paperll, (von Freeden-Jeffry et al., 1995), Ebf1 (paperll, (Lin and Grosschedl, 1995; Zandi et al., 2008), FOXO1(Dengler et al., 2008; Mansson et al., 2012), Pax5 (paperllI, (Nutt et al., 1999a; Rolink et al., 1999; Urbanek et al., 1994). 
With new technologies, more in depth analysis has enabled fine-tuned detection of where in the hierarchy the developmental block takes place in the absence of these critical factors. By using many surface markers simultaneously, defined cell populations can be identified, analyzed and sorted with high purity. However, studying mice carrying mutations in critical genes add a level of complexity since the expression of stage specific surface markers may be altered. For instance, definition of any cell type identified by surface expression of IL7R becomes an issue in mice lacking expression of IL7R. Another notable example is the lack of CD19 expression on B-cell progenitors in Pax5 deficient mice even though the progenitors have activated the B-lineage program (paperIII). Thus we need to investigate not only the surface phenotype of cells, but also their intracellular makeup and their functionality.

\section{Epigenetic regulation}

The prefix "epi-“, is Greek for "above", thus epi-genetics means "above the genes" and the term originates all the way back to Aristotle. Epigenetics as a term in development was first used in 1942 by Waddington, as the study of what lies between the genotype and the phenotype that turn the genetic information into function (Waddington, 2012) (reprint). Epigenetics is the regulation of the chromatin structure and this process act in complex interplay with the general transcription factor networks controlling expression or repression of genes (figure 5). Through epigenetic regulation, the accessibility, or openness, of the chromatin is regulated. This is achieved by for example DNA methylation, where the cysteine residues in $\mathrm{CpG}$ dinucleotides (cytosine next to a guanine) of DNA are coupled to a methyl (CH3) group. About $60-80 \%$ of the $\mathrm{CpGs}$ in humans are methylated. About $10 \%$ of $\mathrm{CpGs}$ are found in clusters called $\mathrm{CpG}$ islands, some of which are unmethylated, and found in the transcriptional start sites of many genes (Smith and Meissner, 2013). The DNA is ordered in a structure by being wound around histone-protein octamers. Specific amino acids in the tails of the histone proteins are in turn subjected modifications such as (but not limited to) acetylation and methylation, and this has been defined as the histone code. Combinations of these modifications will activate or repress transcription, and specific areas in genes can be identified based on the modifications present on histone tails. Examples of this is Histone 3 (H3) lysine 4 (K4) monomethylation (H3K4me1) that can be used to identify enhancer elements, while active promoters are marked by trimethylation of the same amino acid (H3K4me3), in combination with acetylation of multiple $\mathrm{H} 3$ and $\mathrm{H} 4$ residues (Lin et al., 2010).

The status of the chromatin with regard to lineage restricted genes has been shown to change during the maturation of blood cells (Cui et al., 2009; Jeong and Goodell, 2014; 
Weishaupt et al., 2010). Mice that lack expression of Bmil (a component of the polycomb repressor complex 1) had increased numbers of lymphoid progenitors and increased levels of Pax 5 and Ebfl expression (Oguro et al., 2010). Part of this early up -regulation of Pax 5 and $E b f 1$ is likely due to a lack of suppression of $I k z f l$ (discussed below) in the Bmil deficient progenitors (Arranz et al., 2012). Further, the strict regulation of $\mathrm{V}_{\mathrm{H}}-\mathrm{D}_{\mathrm{H}}-\mathrm{J}_{\mathrm{H}}$ recombination where RAG1 and RAG2 must gain access to target gene chromatin is another example. E2A proteins have been shown to bind to the $\mathrm{V} \kappa$ gene promoter and recruit the histone acetyltransferase $\mathrm{CBP} / \mathrm{p} 300$, thereby increasing accessibility of the target genes for transcription and recombination (Hyndman et al., 2012; Sakamoto et al., 2012).

\section{Priming the lymphoid lineage in early hematopoietic progenitors}

At the early stages of development, expression of certain key factors will dictate the initial direction of cell development and although the earliest cells are not yet committed, actions are taking place to prime for development along defined pathways. It has been shown that many genes normally associated with lineage restriction are expressed at low levels already in the earliest progenitors (Hu et al., 1997). Expression of general lymphoid genes such as Rag1, Rag2, Dntt and germline immunoglobulin transcripts can be detected in the LSK compartment, whereas the expression of more B- or T-lineage restricted genes are less frequent (Hu et al., 1997; Igarashi et al., 2002; Mansson et al., 2007; Tudor et al., 2000).

Mice deficient in the transcription factor IKAROS (Ikzfl) (Wang et al., 1996) were shown to have gross developmental defects within the whole hematopoietic compartment, with the exception of erythrocyte and megakaryocyte development. In mice carrying an $I \mathrm{kzfl}^{-/}$ enhancer GFP reporter, GFP can be detected in the LSK compartment, but the cells lacked transcripts of Flt3, IL7ra and Rag1 genes detected in Wt GFP ${ }^{+}$LSKs. In vitro single cell assays demonstrated that $I k z f I^{-/-}$LMPPs lacked B cell potential, displayed considerably reduced $\mathrm{T}$ cell potential but had normal myeloid potential (Yoshida et al., 2006). Another factor involved in lymphoid lineage priming is PU.1 (Sfpi1) (McKercher et al., 1996; Scott et al., 1994) . The proportion of megakaryocyte/erythrocyte progenitors (MEP) in Sfpi $1^{-/}$(PU.1) fetal liver (FL) and BM were not reduced compared to Wt (Iwasaki et al., 2005), whereas the CLP, GMP and CMP populations were diminished (Dakic et al., 2005; Iwasaki et al., 2005). Additionally, PU.1 expressing MPPs did not give rise to Ter $119^{+}$erythroid cells in vivo after transplantation (Arinobu et al., 2007). This indicates that PU.1 expression is increased in the LMPP, which has lost erythro-megakaryocytic potential (Adolfsson et al., 2005). Further, the dose of PU.1 has been shown to be important for myeloid versus lymphoid development in such a way that high PU.1 expression promotes development of myeloid cells and low 
expression promotes development of lymphoid cells (DeKoter and Singh, 2000). This has been suggested to be regulated by IKAROS dependent control of expression of the transcriptional repressor GFI-1 which can replace PU.1 in its own regulatory elements, thus preventing the PU.1 auto-regulatory loop (Spooner et al., 2009). The regulation of PU.1 need careful managing since PU.1 is involved in regulation of the expression of Flt3 (Carotta et al., 2010) defining the LMPP as well as Il7ra (DeKoter et al., 2002) needed for the LMPP to CLP transition.

The Tcfe $2 a$ gene encoding E2A has potential binding sites for IKAROS in important regulatory elements, and E2A and IKAROS share several target genes, suggesting that these factors collaborate to maintain lymphoid priming (Dias et al., 2008). E2a deficient (vav-Cre$\mathrm{E} 2 \mathrm{~A}^{\mathrm{fl} / \mathrm{fl}}$ ) mice experience a three-fold reduction of MPPs and a block in development at the Ly6D-negative stage of the CLP (Inlay et al., 2009). This pattern is true also for $E 2 a^{+/}$mice where the LMPP as well as Ly6D- CLP populations are reduced about $50 \%$ in relation to $\mathrm{Wt}$ (paperIV). When analyzing gene expression in $E 2 a^{+/}$CLPs it was shown that these cells had reduced levels of $\mathrm{B}$ lineage specific genes, indicating defective priming in existing CLPs (paperIV). Hence IKAROS and PU.1, in collaboration with E2A and additional factors such as BCL11a (Liu et al., 2003; Yu et al., 2012), are involved in initiating lymphoid lineage priming in early progenitors.

\section{Cytokine signaling, Flt3 and IL7R in B lymphoid development}

Surface receptors Flt3 and IL7R are central for defining the CLP, and proliferation and survival assays on sorted CLPs and modified BaF3 cell lines demonstrated that Flt3 and IL7R act in distinct synergy promoting proliferation (paperI). Mice deficient in either Flt3Ligand (McKenna et al., 2000; Sitnicka et al., 2002) or Flt3 (Mackarehtschian et al., 1995) have normal lymphocyte levels in the periphery, but apparent reductions in common lymphoid progenitors (CLPs) as well as in Flt3 ${ }^{+}$LSK cells. Mice deficient in IL7 (von Freeden-Jeffry et al., 1995) or a functional IL7R (Peschon et al., 1994) also have severely impaired Blymphocyte development, and the few $\mathrm{CD} 19^{+}$cells that can be detected in adult $I L 7^{-\alpha}$ mice are of a B1-B cell (embryonic) origin (Carvalho et al., 2001). In a further study on mice lacking function of both the pathways, a strong enhancement of the phenotype was found with no B lymphocytes detectable in the periphery (Sitnicka et al., 2003).

Signaling by IL7 is however not only of importance for proliferation and expansion of early progenitors, but also has instructive capacities in differentiation towards the B cell lineage. While previous studies claim that pre-pro-B cells derived from $I L T^{\wedge}$ mice have lost 
their B lineage potential (Kikuchi et al., 2008) a more recent paper show that B lineage potential is intact in these mice (paperII). This discrepancy can be explained by the generously defined $\mathrm{B} 220^{+} \mathrm{CD} 43^{+}$pre-pro-B cell population analyzed in the initial report (Kikuchi et al., 2008). In addition, CLPs purified from IL7 deficient mice (ILT ${ }^{-}$) have been reported to have dramatically reduced B cell potential that can be partially rescued by ectopic EBF expression (Dias et al., 2005) however, this finding is likely explained by differences in the kinetics of B-cell formation as a result of the lack of Ly6 ${ }^{+}$CLPs in IL7 deficient mice (paperII). Combined stimulation with IL7 and Flt3L did not result in significant increase of gene expression of $B c l 2$ and $B c l-X L$ in a modified $\mathrm{BaF} 3$ cell line (paperI), and $\mathrm{B}$ cell development can also not be rescued by ectopic expression of Bcl2. T cell development in contrast can be partly rescued by Bcl2 expression (Jensen et al., 2008; Kondo et al., 1997a; Maraskovsky et al., 1998) and this suggests that IL7 is permissive in T cell development. Binding of IL7 to IL7R will result in phosphorylation and activation of the receptor which in turn will recruit adaptor proteins such as signal transducer and activator of transcription 5 (STAT5) that upon phosphorylation transfer to the nucleus and act as TFs (Goetz et al., 2004). STAT5a/b have been demonstrated to have essential roles in lymphopoiesis (Teglund et al., 1998; Yao et al., 2006). In 2009, Malin et al stated that IL7 was not (via activation of STAT5) involved in activation of Ebfl and Pax5, these data were however compromised by the fact that the use of a Ragl-Cre-Stat ${ }^{\mathrm{fl} / \mathrm{fl}}$ mouse deletes the function of IL7 after its downstream pathway has already been initiated (Malin et al., 2009). IL7 does however not appear to be involved in the reduction of myeloid potential in the LMPP to Ly6 $\mathrm{D}^{-}$transition, since these cells from $W t$ and $I L 7^{--}$mice had comparable myeloid potential (paperII). This suggests that the earliest actions of lymphoid lineage restriction are independent of IL7, but that IL7 is required for establishment of the B cell genetic network already in the CLP compartment.

\section{Transcription factor networks in early B lineage commitment}

Whereas E2A, IKAROS and PU.1 are more general lymphoid driving transcription factors, Pax5 and EFB1 are specifically expressed in the B lymphoid lineage (figure 5). Commitment to the B lineage has been shown to precede the surface expression of traditional B lineage markers such as B220 and CD19. These early committed cells could be detected by the surface expression of a $\lambda 5$-promoter regulated hCD25 reporter gene and constituted about $5 \%$ of the total CLP compartment (Mansson et al., 2008). Wt LMPPs, CLPs and hCD25 CLPs displayed 0, 14, and 50\% co-expression of Pax5 and Ebfl in a single cell assay (Mansson et al., 2008) supporting the idea that the B-lineage program is activated in the reporter expressing cells. 


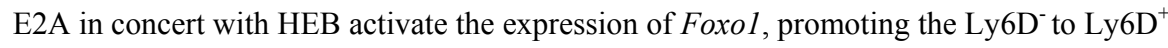
transition (Welinder et al., 2011). Foxol deficient and Ebfl deficient mice demonstrate highly similar phenotypes, and FOXO1 and EBF1 act in a positive feedback loop, stabilizing the B lineage program and promoting exit from the CLP-stage (Mansson et al., 2012). The combined actions of E2A, EBF and FOXO1form a network crucial for the development of B cells (Lin et al., 2010). When transplanting $E b f 1^{-/}$fetal liver progenitor cells, the identification of phenotypic CLPs was possible, however they did not have proper expression of B lineage genes, including Pax5 (Lin and Grosschedl, 1995; Zandi et al., 2008). Also, $E b f 1^{-/}$mice retain the NK-developmental capacity in Ly6D ${ }^{+}$CLPs (paperII) and several genes that are expressed in NK cells are up-regulated in $E b f 1^{+-}$pro-B cells (Lukin et al., 2011), indicating that EBF1 has a function in repressing the NK lineage fate. This ability of EBF1 to both regulate B cell genes and also suppress other lineage genes seems to be independent of E2A and Pax5 functions, since EBF1 can induce B-lineage restriction also in the absence of E2A (Seet et al., 2004) or Pax5 (Pongubala et al., 2008). As for E2a $a^{-/}$CLPs (Bain et al., 1994; Bain et al., 1997; Zhuang et al., 1994) even though Ly6D ${ }^{+}$CLPs are present in $E b f 1^{-/}$animals in increased numbers (paperII), the Ebf1 $1^{-/}$CLPs lack D-Jrearrangement of the immunoglobulin heavy chain (Lin and Grosschedl, 1995) and both EBF1 and E2A can interact with the B lineage specific E-Rag enhancer (Hsu et al., 2003; Zandi et al., 2008).

EBF1 was directly linked to IL7-signalling due to the ability of STAT5 to not only induce expression of Ebf1, but also partially rescue B-cell development in the absence of IL7-signal (Kikuchi et al., 2005). The Ly6 $\mathrm{D}^{+}$CLPs that developed in an $I L \tau^{\circ}$ mouse displayed normal B cell developmental properties in vitro when cultured with IL7, however with highly increased NK-potential and reduced B cell-restriction when stimulated with Notch signal (paperII). Notch1 plays a major role for the development of T-lymphocytes and has been shown to be negatively regulated by EBF1 (Nechanitzky et al., 2013) and Pax5 (Souabni et al., 2002). Expression of constitutively active Notch1 in BM cells resulted in development of thymic independent T cells in BM and an early block in B cell development (Pui et al., 1999). In addition, Notch1-deficient mice display a block in $T$ cell development at an early progenitor stage with development of B cells in thymus (Radtke et al., 1999) and when Notch $^{-/}$BM cells were intrathymically transplanted to congenic mice, phenotypic B cells developed (Wilson et al., 2001). In progenitor cells in the BM, Notch1 signaling has been suggested to be actively repressed by the presence of LRF (leukemia/lymphoma related factor) and that only the abundance of Notch ligands in the thymus can overrule the cell intrinsic LRF-inhibitory activity (Maeda et al., 2007). 


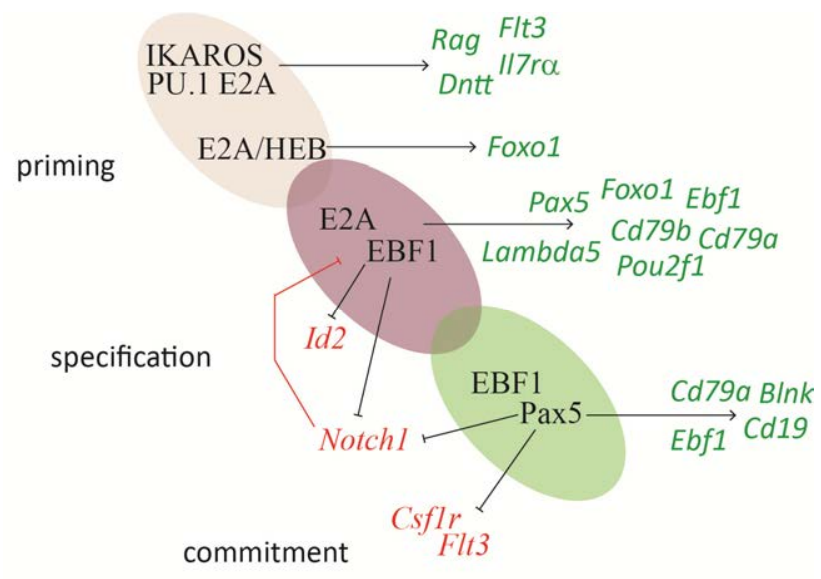

Figure 5. Transcription factor networks in hematopoietic development. This schematic drawing provides an overview of central transcription factors (capital letters) and gene regulation (in italics) during early hematopoietic development. Green text indicates positively regulated genes and red text indicates negatively regulated genes.

Pax5 has been posted as a the major factor responsible for determination of the B lineage (Urbanek et al., 1994). However, the presence of $\mathrm{V}_{\mathrm{H}}-\mathrm{DJ}_{\mathrm{H}}$ rearrangements in progenitors (Nutt et al., 1997), and the low Pax5 expression in cell types preceding the committed B cell (Anderson et al., 2007; Fuxa and Busslinger, 2007; Mansson et al., 2008) rather indicates Pax 5 as being essential for continued stable commitment and expression of B lineage genes initiated by E2A and Ebfl (O'Riordan and Grosschedl, 1999). Pax5 gene expression is low or undetectable in the CLP compartment (Fuxa and Busslinger, 2007; Mansson et al., 2008) but is increased specifically in the Ly6 $\mathrm{D}^{+}$fraction (Mansson et al., 2009). However, also in the absence of Pax5, a transcriptional program specific for B lineage is initiated (paperIII, (Nutt et al., 1998; Nutt et al., 1997) and the expression of many B lineage specific genes was specifically reduced in $\mathrm{Ebfl}^{-/}$progenitors, and not in $\mathrm{Pax}^{-/-}$progenitors (paperIII). Despite this apparently activated B lineage program, these Pax5 deficient cells are not stable in their commitment and Notch signaling or cytokine stimulation is sufficient to drive these cells into alternative cell fates in vitro and in vivo (paperIII, (Cobaleda et al., 2007; Heavey et al., 2003; Hoflinger et al., 2004; Nutt et al., 1999b). By transplanting Pax $5^{-/}$fetal liver cells to host mice it was shown that Pax 5 deficient cells can repopulate the $\lambda 5$-reporter expressing $B$ 
committed population (paperIII). These cells however do not express CD19 since Pax5 is a major activator of the CD19-gene. The $\mathrm{Pax}^{5^{-\alpha}}$ progenitors did not have defect expression of other lineage genes and Pax5 expression seems to be of importance for the further commitment of already B lineage primed cells (paperIII). In line with this, $\operatorname{Pax} 5^{+/} \lambda 5$-hCD25 reporter positive cells displayed in vitro plasticity to Thy $1.2^{+} \mathrm{CD}^{+} \mathrm{T}$ cells (paperIV). Transplanted $\mathrm{Pax}^{-/-} \mathrm{B} 22 \mathrm{C}^{+} \mathrm{Kit}^{+}$progenitor cells were shown to fully reconstitute the $\mathrm{T}$ cell lineage, showing that Pax5 is redundant for the development of T cells (Rolink et al., 1999). Also, the development of CD19 positive cells in E47 deficient cells could be rescued by overexpression of EBF1, however not by expression of Pax5, indicating that EBF1 acts upstream of Pax5 (Seet et al., 2004). Expression of Pax5 will down regulate Flt3-expression further locking the B-cell fate (Holmes et al., 2006) and in addition to Notch1 Pax5 also repress other non B-lineage genes such Csfrl (Tagoh et al., 2004). Also, overexpression of Ebf1 and not Pax5 in Runx1 ${ }^{\mathrm{F} / \mathrm{F}}$-mb1-Cre cells could restore expression of E2A, Ebf1 and Pax5, as well as restore the lacking $\mathrm{V}_{\mathrm{H}}-\mathrm{DJ}_{\mathrm{H}}$ rearrangement (Seo et al., 2012). It has further been reported that conditional targeting of either the Pax5 or Ebfl genes in CD19 ${ }^{+}$cells, resulted in disruptions of the genetic program with a resultant loss of B-cell identity allowing the cells top adopt alternative cell fates (Cobaleda et al., 2007; Nechanitzky et al., 2013; Nutt et al., 1999a; Rolink et al., 1999).

At the pre-B cell stage, B lineage genes $\lambda 5$ and $V p r e B$ increase greatly in expression and pre-BCR expression will enable cells to respond and proliferate in low concentrations of IL7 (Marshall et al., 1998; Ochiai et al., 2012). When analyzing $E b f 1^{+-}$pre-B cells, a reduction in surface pre-BCR was detected and the cells also had a reduced response to IL7 (paperIV). Additionally, $\mathrm{Ebfl}^{+/}$pro-B cells have reduced expression of cell division and mitosis genes. This in combination with reduced surface expression of IL2R (CD25) likely explain the partial block in $G_{1}$ of the cell cycle (paperIV). This block is consistent with the $G_{1}$ arrest in the pro-B compartment of Ebf1 deficient cells (Gyory et al., 2012). However, the $E b f 1^{+/}$cells did not show increased signs of apoptosis, as did the Ebfl deficient cells, and this suggests that EBF1 dose has a role in expansion and survival of B-cells (paperIV, (Gyory et al., 2012). 


\section{The role of transcription factors and signaling molecules in lymphoid neoplasms}

Since transcription factors and signaling molecules play such major roles throughout B cell development in terms of survival, differentiation and lineage specification, they are also likely to have major impact in the process of malignant transformation. The term "lymphoid neoplasm" covers many blood cell diseases that are subdivided based on a range of criteria formulated in the 2008 WHO classification, discussed by Campo et al in (Campo et al., 2011). These criteria cover cell surface phenotype (determined by flow cytometry), morphology, cytogenetic analysis (chromosomal alterations such as fusion proteins, deletions etc.), status of immunoglobulin-rearrangement, chronic versus acute disease, and tissue localization. The general genetic heterogeneity of blood cell disorders and the many different subtypes and underlying genetic defects make treatment complicated and thus studies of the molecular mechanisms are of the essence.

In different neoplastic subtypes a number of commonly recurring genetic changes can be identified that also can be used as prognostic factors and for therapeutic implications. Major causes for cancers of the blood are gene rearrangements giving rise to constitutively active fusion-proteins. One such example is the $\mathrm{t}(9 ; 22)(\mathrm{q} 34 ; \mathrm{q} 11)$ translocation between Abelson tyrosine kinase $(\mathrm{ABL})$ and the breakpoint cluster region $(\mathrm{BCR})$ resulting in the fusion protein BCR-ABL found in about $95 \%$ of patients with chronic myeloid leukemia, 30\%-50\% of adult patients with acute lymphoblastic leukemia (ALL) (le Coutre et al., 1999)and approximately $2 \%$ of the pediatric B cell ALLs (Inaba et al., 2013). The prognosis for patients positive for BCR-ABL was much improved with the discovery of specific chemotherapy in the form of Imatinib, a drug that locks the BCR-ABL kinase in its inactive state (Druker et al., 2001; Druker et al., 1996), followed by second generation drugs such as Dasatinib (Shah et al., 2004), that instead target the active state of the kinase.

Many lymphoid neoplasias carry rearrangements of genes to parts of the Ig loci and the naturally occurring rearrangement and cut and paste action of immunoglobulins could be a reason for genetic instability in developing lymphocytes. An example is Burkitt's lymphoma where chromosomal translocations that juxtapose oncogene MYC (8q24) to one of the immunoglobulin loci, resulting in deregulated MYC expression. This MYC activity is however not sufficient for leukemogenesis and genetic alterations affecting the TCF3 gene (mouse Tcfe $2 a$ equivalent) either directly, or even more commonly, by loss-of-function mutations in TCF3-regulator ID3, was seen in 70\% of sporadic Burkitt's lymphoma cases (Schmitz et al., 2012). In a second study, 68\% of defined Burkitt's lymphoma cases carried potentially damaging mutations in ID3 (Richter et al., 2012). 
Detailed studies from several groups have shown that also the copy number alterations (CNAs) of genes involved in differentiation, proliferation, cell cycle and transcription add to the complexity of the disease. Deletions and loss-of-function mutations in genes regulating lymphoid development, such as PAX5, TCF3 (Tcfe2a), EBF1 and IKZF1 are found in around two out of three pediatric B-acute lymphoblastic leukemia (B-ALL) cases (Inaba et al., 2013; Kuiper et al., 2007; Mullighan et al., 2007). Mutations of PAX5, EBFI and IKZFI were also found in adult ALL cases (Safavi et al., 2014). The most commonly affected gene is that of PAX5 (one-third of pediatric B-ALL), but fortunately alterations in PAX5 are also not associated with poor outcome. Lesions in PAX5 are found also in T-ALL cases but to a lesser extent than in B-ALL cases, whereas EBFI and IKZFI deficiency mainly result in B cell malignancies (Kuiper et al., 2007).

A recent study demonstrates that these CNA in their own right can be used as prognostic tools. For instance, the absence of copy number alterations in EBF1, IKZF1, PAX5, or isolated deletions of $P A X 5$, were classified as good risk genetic abnormalities, whereas any deletion of $I K Z F 1$ or $E B F 1$ were classified as poor risk genetic abnormalities (Moorman et al., 2014). In the previously mentioned BCR-ABL1 positive B-ALL, 70-80\% of patients also carry somatic mutations in $I K Z F 1$ and this combination is associated with a poor outcome of disease (Iacobucci et al., 2009; Martinelli et al., 2009; Mullighan et al., 2008). It should be noted that a subtype representing about $10 \%$ of pediatric B-ALL are the BCR-ABL1-like, which have a genetic expression profile very similar to the BCR-ABL1 ${ }^{+} \mathrm{ALL}$, including alterations in $I Z K F 1$ and a very poor outcome, but without the BCR-ABL1 translocation (Den Boer et al., 2009; Mullighan et al., 2009).

The relevance of transcription factor dose was investigated in studies on mice where it was shown that by reintroducing Pax5 in induced leukemic cells, a process resembling normal B cell development could be restored (Liu et al., 2014). Also, haploinsufficiency of either Pax5 or Ebfl could synergize with constitutively active STAT5 to give rise to ALL in $100 \%$ of investigated mice, with a low risk for developing disease with only the transcription factor deficiency present (Heltemes-Harris et al., 2011). Studies have also shown that BCR-ABL in chronic myeloid leukemia (CML) can induce PAX5 mediated transcriptional suppression of myeloid lineage repressor BACH2 (Casolari et al., 2013; Itoh-Nakadai et al., 2014) and EBF1 repressor proteins ZNF521 (Warming et al., 2003; Yamasaki et al., 2010) and ZNF432 (Harder et al., 2013) have been found to be up-regulated in B-ALL. Further, the frequency of lesions in $E B F 1$ and $I K Z F 1$ in twenty pediatric B-ALL relapse cases were found to be higher in the relapsed cases relatively to the newly diagnosed B-ALL: EBF1 $25 \%$ vs $4.2 \%$ and IKZF1 35\% vs 8.9\% (Yang et al., 2008). This data indicates that the dose of key transcription 
factors is an important player in the progression of disease, and may relate to the existence of leukemia initiating cells and reasons for relapse of disease (Notta et al., 2011). 


\section{METHODS}

Detailed descriptions of used methods are found in the papers included in this thesis. Some methods that are recurring and of central importance for the work are described and discussed more in detail in the following section.

\section{Flow cytometry}

Most of the data in this thesis is based on the use of flow cytometry and fluorescence activated cell sorting (FACS). Flow cytometry is a powerful tool that allows investigation of a wide combination of surface markers and intracellular molecules on single cells in suspension. With FACS we can sort out large and small cell populations that later can be subjected to downstream analysis like cell culture assays or molecular biology assays.

\section{Brief introduction to flow cytometry}

The flow cytometer can analyze cells in single cell suspension, one by one, and for each determine the expression of pre-antibody-marked surface or intracellular molecules. This detection is possible due to conjugation of the antibodies to different fluorochromes, that can be excited by lasers and the resulting emitted light can be captured by the machines detectors. Moreover, size and general granularity of the cell can be analyzed via the scattering of light as it hits the cell (Brown and Wittwer, 2000).

When selecting antibodies (fluorochromes), you need to know which lasers and also which filters your particular flow cytometry instrument is equipped with. A modern flow cytometer will in general have 2-4 lasers, and on an imagined four laser instrument these might be a $405 \mathrm{~nm}$ (violet), a 488nm (blue), a $561 \mathrm{~nm}$ (green) and a 633 (red) laser. The indicated color represents the wavelength emitted by that particular laser (figure 6). The optimal choice of antibodies is also dictated by a combination of abundance of the molecule of interest, in combination with the intensity of the fluorochrome.

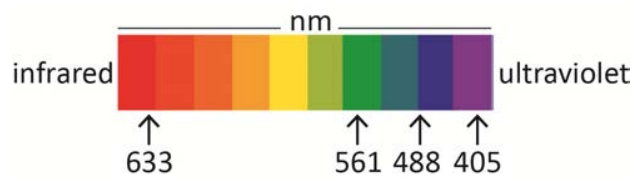

Figure 6. Visible light region of the electromagnetic spectrum. The wavelength (in nano meters) and color of each laser in a presumed 4-laser instrument is indicated. 
There are many fluorochromes, but they all follow the same principle. Light from a laser excites electrons in the fluorochrome molecule and when these return to their ground state, light is emitted at a longer wavelength. This emitted light is reflected or pass through a series of filters that separate light of different wavelengths to enable detection of light from several sources simultaneously. Some fluorochromes will give rise to emitted light of overlapping spectrums, and this poses a problem since it might result in false positive detection. This problem is circumvented by semi-automatic compensation-functions in modern flow cytometers. Compensation means that the software will calculate how much of the detection of fluorochrome $\mathrm{X}$, is actually detection of spillover from the fluorochrome $\mathrm{Y}$, and deduct this automatically. If you are only using a few parameters for the analysis of a sample, compensation issues can be mostly avoided by thoughtful choice of colors (Brown and Wittwer, 2000; Johansson and Macey, 2011).

\section{Data analysis - understanding your samples}

When you have chosen the most optimal panel of fluorochromes for your analysis it is time for data acquisition and data analysis. There are a number of things to consider to avoid misinterpretation of data, and below is a summary of a few things to take into consideration (Johansson and Macey, 2011; Rundberg Nilsson et al., 2013).

Analysis of rare events, how common is your cell type? This will dictate how many thousands or millions of cells to stain from your tissue sample. If your target cell is found $1 / 50.000$, recording 10.000 events might give you false negative data.

Compensation - which antibody do I choose? Compensation should be performed with the same antibody as you intend to use in your experiment. This applies particularly to tandem conjugate dyes, where each batch of antibody can vary with regards to intensity.

Setting the gate, what is a positive and negative population? To answer this question, you need to stain control samples such as fluorescence minus one (FMO) controls. This means that you would stain one aliquot of cells with all the antibodies in your setup except for \#1, one aliquot with all antibodies except for \# 2 etc. This will give you a good idea on where your negative population is, control the compensation, and detect any interference between fluorochromes. To fully rule out fluorochrome interference, single color stained controls are also recommended.

What's in a name? In a perfect world, all research groups would use exactly the same sample preparation protocols as well as defining markers to detect a specific cell type. This is 
however not, and most likely never will be, the case, since knowledge is always increased and methods change. What we can do is to always be very precise when explaining our analysis.

\section{Mouse models}

The mouse has shown to be an excellent model to study hematopoiesis. Since the knowledge of the murine hematopoietic system is so extensive, it can be used to study basically all levels of both the adult and fetal murine systems. Although it will not be discussed in detail, I however wish to emphasize that results based on the use of animal models should not without thought be transferred to humans. The two species are separated by 65-75 million years of evolution, have huge difference in size and life span, and also meet different pathogenic challenges. This topic is reviewed in (Mestas and Hughes, 2004; Payne and Crooks, 2007; Schmitt et al., 2014).

By creating mice with knock-out alleles, controlled breeding allows for studies of both heterozygote as well as homozygote mice. However, complete knock out of a gene will in many cases also not be compatible with life, preventing studies on the adult hematopoietic system. This can be circumvented by using of the vavCre transgenic mice, where Cre under the control of hematopoietic restricted vav gene regulatory sequences makes it possible to specifically study a gene only in the hematopoietic system(Georgiades et al., 2002). Creation of reporter constructs has also made it possible to investigate live cells with regard to intracellular factors. Cells can be detected by flow cytometry based on gene specific regulation as in the Rag1-GFP (Mansson et al., 2009) and $\lambda 5$-hCD25 (Martensson et al., 1997) reporters. The ability to genetically modify almost any sequence of interest and to be able to study this change in vivo has made it possible to learn about complex processes impossible to study with only human samples. Recent advances in genome engineering using the CRISPR-Cas9 system has enabled faster generation of transgenic models, reviewed in (Hsu et al., 2014; Sander and Joung, 2014).

For the papers in this thesis we have relied on a number of different transgenic or congenic mice, all of the C57BL6 strain, which is the most commonly used mouse strain. At large, different mouse strains are alike; however some molecules used for surface identification of cells in this thesis are expressed differently between strains. Natural Killer (NK) cells in C57BL6 mice co-express NK11 and DX5, whereas other strains lack expression of NK11 and have to rely on DX5 expression. Thy1 (CD90) was initially detected on T-lymphocytes and this pan-T-lineage marker exists in two versions, differing by only one amino acid. These are 
called Thy1.1/CD90.1 and Thy1.2/CD90.2 with the latter being expressed by C56BL6 strain. CD45 (also called leukocyte common antigen) is expressed on all hematopoietic cells with the exception of thrombocytes and mature erythrocytes, and exists in two allelic variants, CD45.1 and CD45.2. This surface molecule is widely used as a way to separate donor from host in transplantation assays in mice.

\section{In vitro evaluation of lineage potential}

Even though transplantation assays is the best way to evaluate the lineage potential of different cell populations, robust in vitro methods for lineage evaluation are very helpful in lowering cost, increase sample size and reduce the number of animals. One such method is the use of stroma cell-leukocyte co-cultures where the cytokine and signaling conditions can be controlled. The OP9 stroma cell line has a fibroblast-like morphology and was derived from the BM of newborn op/op mouse calvaria (Kodama et al., 1994). Due to a mutation in the gene encoding macrophage colony stimulating factor (M-CSF) the cells do not produce this cytokine and have a low efficiency for generating macrophages in vitro, and a high efficiency for generating B cells in vitro. Co-culture of hematopoietic progenitor cells with OP9 and a combination of IL7, Kit-ligand and Flt3-ligand will further increase the efficiently in differentiation to $\mathrm{CD} 19^{+} \mathrm{B}$ cells (Zetterblad et al., 2010). Additionally, conditions allowing for the evaluation of NK and DC lineage can be induced by including cytokines IL2 and IL15 (Rosmaraki et al., 2001) to the OP9 co-culture. Stable expression of the Notch-ligand Deltalike 1 in the OP9 cells (OP9-Delta), created an efficient co-culture system for the production of T-cells expressing CD3, Thy1/CD90 and TCR $\beta$ (Schmitt and Zuniga-Pflucker, 2002). 


\section{RESULTS AND DISCUSSION}

\section{Paper I}

To study the combined effect of Flt3 and IL7R signaling pathways, in paper I we sorted CLPs and performed short term in vitro studies showing us that the combined action of Flt3L and IL7 generated greater cell numbers than either of the cytokines alone. We confirmed this in the $\mathrm{B} 220^{+}$cell line BaF3 (Palacios and Steinmetz, 1985) modified to stably express Flt3 as well as IL7R $\alpha\left(\mathrm{BaF}^{\mathrm{Flt3}+\mathrm{IL} 7 \mathrm{R}+}\right)$. Staining $\mathrm{BaF}^{\mathrm{Flt3}+\mathrm{IL} 7 \mathrm{R}+}$ with Annexin-V demonstrated a clear increase in apoptotic cells in the absence of cytokines. By running quantitative real time PCR on the $\mathrm{BaF}^{\mathrm{Flt3+IL7R+}}$ as well as on in vitro cultured CLPs we could conclude that Flt3L and IL7 prevents apoptosis by reducing the levels of pro-apoptotic genes such as Bim/Bcl2l11 and $\mathrm{Bad}$, but the effect on gene expression levels was at the most additive with combined stimulation with Flt3L and IL7. Further studies using the fluorescent proliferation dye CSFE showed us that CLPs growing with both cytokines present are dividing faster than single stimulated cells. By Western Blot analysis of phosphorylated proteins upon stimulation of $\mathrm{BaF}^{\mathrm{Flt3}+\mathrm{IL} 7 \mathrm{R}+}$ cells with different combinations of the cytokines, we detected activation of separate signaling pathways, where Flt3 signaling cooperate with activated STAT-5 and give cell expansion.

We conclude that Flt3 and IL7R signaling act in synergy on the same cell to expand the CLP population and this is mediated through activation of separate downstream pathways.

\section{Paper II}

With Paper II, we set out to further investigate the early hematopoietic progenitors in mice deficient in IL7 $\left(I L 7^{-/}\right)$. We could report statistically significant reductions in cell numbers already in the early IL7R negative LMPP compartment, and a clear 5 fold difference in total CLPs. By introducing the Ly6D surface marker we found that this reduced CLP population is the result of a close to complete loss specifically of the Ly6 $\mathrm{D}^{+}$CLPs. By analyzing $\mathrm{Wt}$ and $I L 7^{--}$CLPs we could see that while $12 \%$ of the Wt single cells analyzed coexpressed several B lineage associated genes, there was no such co-expression of genes in the $I L T^{\text {- }}$. By co-culturing CLPs with OP9 stroma cells under conditions optimal for B cell development, we show that CLPs from $I L T^{\circ}$ mice, although deficient in their in vivo B lymphoid priming, remain IL7 responsive and have normal B cell potential in vitro. However, when instead co-culturing only the Ly6 $\mathrm{D}^{+}$CLPs from either Wt or $I L 7^{-/}$mice with OP9 
stroma under conditions supportive of NK and DC development, we see that Ly6 $\mathrm{D}^{+}$CLPs from the $I L T^{/-}$are displaying functional differences. Wt Ly6D ${ }^{+}$CLPs will still mainly give rise to pure B cell colonies, whereas CLPs developing under IL7 deficient conditions are not properly lineage restricted and express both NK11 and CD11c. One possible explanation for this lack of restriction in the $I L T^{/-}$Ly $6 \mathrm{D}^{+}$cells could be reductions in critical factors potentially downstream of IL7R-signaling. The expression of transcription factor EBF1 had previously been shown to be up regulated in the Ly6D- to Ly6D ${ }^{+}$transition (Inlay et al., 2009; Mansson et al., 2009). We thus analyzed the mRNA expression of Ebf1 in sorted Ly6 $\mathrm{D}^{-}$and Ly $6 \mathrm{D}^{+}$CLPs and while both Wt and $I L T^{/-}$Ly6D ${ }^{-}$cells express no/very low levels of $E b f 1, \mathrm{Wt}$ Ly $6 \mathrm{D}^{+}$cells have very high $E b f l$ expression, which is strongly reduced in cells from the $I L T^{\prime}$ mice. We next studied Ebfl deficient mice $\left(E b f 1^{-/}\right)$, and found that the distribution between Ly6D ${ }^{-}$and Ly6D ${ }^{+}$cells is normal. However, by culturing also $E b f 1^{--}$deficient CLPs under B, NK and DC promoting conditions we could see that $100 \%$ of cells from $E b f 1^{-/}$mice expressed NK11.

We conclude that IL7R-signalling is essential for the proper induction of Ebfl expression and appropriate lineage restriction in the CLP compartment.

\section{Paper III}

In paper III we aimed to study Pax5, another transcription factor central to B cell development. Cells deficient in Pax5 will not express CD19 on the surface, and this poses a challenging problem since CD19 is a defining marker for B cell lineage. To work around this issue we used the hCD25 reporter mouse, providing surface marker based detection of cells with an activated B lineage program. Pax 5 deficiency $\left(\operatorname{Pax} 5^{-/}\right)$is highly embryonically lethal, and thus we extracted fetal livers of $\mathrm{Wt}$ and $\mathrm{Pax}^{--}$embryos and transplanted them to congenic CD45.1 mice. When analyzing the bone marrow of these mice 4-6 weeks after transplantation we found that the donor $\operatorname{Pax}^{-/}$cells had repopulated both the LSK and CLP compartments, however to a lesser degree than the $W t$ cells. The $\mathrm{Ly} 6 \mathrm{D}^{+} \mathrm{hCD} 25^{+}$population was highly increased in the $\operatorname{Pax}^{-/-}$transplanted mice and SC-PCR analysis of these cells displayed normal expression of B-lineage genes. This indicated to us that the cells despite lacking Pax5, still could initiate the B cell program in the earlier hematopoietic progenitors. This accumulation of reporter positive cells was also apparent within the $\mathrm{B} 220^{+}$population where hCD $25^{+}$cells were increased from $15 \%$ in $W t$ to approximately $80 \%$ in the $\operatorname{Pax}^{-/-}$. Since we could not use CD19 to identify cell types, we here defined B220 $0^{+} \mathrm{CD} 43^{+} \mathrm{hCD} 25^{+}$ 
cells as pro-B cells, and these cells also had a gene expression pattern as the Wt pro-B cells based on microarray analysis. By SC-PCR and q-PCR we studied the levels of non B-lineage genes and found that $\mathrm{T}$ cell genes $\mathrm{Cd} 3$ and Notchl as well as myeloid gene Mpo were increased in $\mathrm{B} 220^{+} \mathrm{hCD} 25^{+} \operatorname{Pax}^{-/-}$cells. To further evaluate the cells in a functional assay,

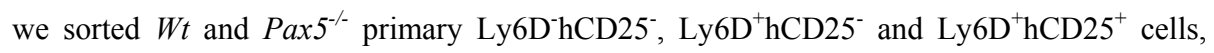
representing progressing states of commitment. The cells were sorted directly to OP9 or OP9Delta stroma under conditions to promote either NK or T cell development. In the cultures of hCD25 cells no difference in lineage potential could be seen between $W t$ and $\mathrm{Pax}^{-/-}$cells. However, the Ly6D $\mathrm{D}^{+} \mathrm{hCD} 25^{+}$cells from $\operatorname{Pax}^{-/-}$mice had lost their B lineage restriction in comparison to $W t$ and the outcome cells represented mixtures of $\mathrm{B}, \mathrm{T}$ and NK cells. Clones from $W t \mathrm{Ly}_{6} \mathrm{D}^{+}$cells had low or no NK1.1 present at the surface, supporting the idea that Ly6D-expression is associated with a reduced NK cell potential.

We conclude that the $\operatorname{Pax}^{-/}$progenitors are able to initiate the expression of B lineage genes, but they are not capable of preventing expression of genes related to other lineages.

\section{Paper IV}

In paper IV we studied the effect on hematopoietic development in mice heterozygous in expression of transcription factors $E 2 a, P a x 5$ or Ebfl. In the CD19 negative progenitor compartments, we detected reductions in LMPP and CLP in the $E 2 a^{+/}$mice. Also the Ly $6 \mathrm{D}^{+} \mathrm{hCD} 25^{+}$and pro-B cells were specifically down in the $E 2 a^{+/}$mice with low reductions in the $\mathrm{Pax5}^{+/-}$or $\mathrm{Ebfl}^{+/-}$animals. When analyzing the $E 2 a^{+/-}$CLP with SC-PCR it was clear that the $E 2 a^{+/}$cells have impaired B lineage specification with less frequent expression of B lineage genes Pax5, Lambda5, Cd79a and OcaB. By performing a myeloid cell promoting assay on sorted LMPPs and Ly6D־CD25 CLPs we detected no difference in myeloid ability between $W t$ and heterozygous cells. However, when analyzing the in vitro ability of single or double heterozygous $\mathrm{Ly}_{6 \mathrm{D}^{+}} \mathrm{hCD} 25^{-}$cells to take on different lineage fates, the $E 2 a^{+/}$cells gave rise to $61 \%$ clones containing NK1. $1^{+}$and/or CD11 $\mathrm{c}^{+}$cells, in comparison to 17,12 and $23 \%$ for $W t, \mathrm{Pax}^{+/-}$and $E b f 1^{+/-}$cells respectively. Reduced $E b f 1$ levels did not appear to have any visible effect in the early hematopoietic compartments, but the $E b f 1^{+-}$mice did show impaired development of pre-B and mature B lineage cells. As has been previously shown there was also an apparent synergy between $E 2 a^{+/-}$and $E b f 1^{+/}$in double heterozygous mice where pre-B cells were down about 6-fold in total numbers. Among other genes, $E b f 1^{+/}$ pre-B cells had reduced expression of IL2ra (CD25). This reduced expression was also 
confirmed at the protein level by staining cell surface IL2Ra and subsequent flow cytometry analysis. Flow cytometry analysis could also confirm that there existed a change in the cell cycle in $E b f 1^{+/}$mice with a partial block in the $\mathrm{G}_{1}$ phase. To be able to further investigate how EBF1 dose affects cell expansion we transduced $E b f 1^{-/}$bone marrow cells with retroviruses expressing either full length $E b f 1$ or Ebfl-ER (estrogen receptor). Culture of Ebfl-ER cells in tamoxifen will allow for EBF1 to enter the nucleus. When removing tamoxifen from the cultures, EBF1-ER will be sequestered in the cytoplasm and this negatively affected the expansion of the cells. This was also directly related to the given dose of tamoxifen, meaning the dose of nuclear EBF1. Using a next-generation sequencing based approach, we next performed an analysis on the complexity of VDJ-rearrangements in pre-B cells from $\mathrm{Wt}$ and $\mathrm{Ebfl}^{+/}$mice, however no differences between the genotypes could be detected, supporting the idea that the full pre-B cell compartment has disturbed expansion. As well as finding that the expression of IL2Ra was reduced, we also saw reductions in the IL7Ra expression. In paper II we show that $I L T^{\alpha}$ mice have reduced $E b f 1$ levels. We therefore cultured $\mathrm{EbfI}^{+/}$pro-B cells in decreasing concentrations of IL7 and this demonstrated that the $\mathrm{EbfI}^{+-}$cells grew less efficiently in low IL7-concentrations as compared to $W t$ cells. We also detected reduced surface expression of pre-BCR on the pre-B cells.

In conclusion, $E 2 a^{+-/}$progenitors have disturbed lineage commitment both $E 2 a^{+/}$and $E b f 1^{+/}$mice had alterations in cell population size relative to $\mathrm{Wt}$, however the loss of on allele of $E b f 1$ is specifically important for the normal expansion of already B-committed progenitors. We have shown that there exists a TF dose-dependent regulation in $\mathrm{B}$ cell development.

\section{Paper V (manuscript)}

After having studied the single heterozygous mice and noticed decreases in cell populations, partial blocks in development and disturbed functions in the outcome cells, we wanted to study the effect of combined reductions of functioning factors. In paper $\mathbf{V}$ (manuscript) we found that a $\operatorname{Pax}^{+/} E b f 1^{+/}$(transheterozygote, TH) mice will have a profoundly disturbed hematopoietic development. Already in mice aged 8-12 weeks we detected partial blocks in development and reductions in total number of early B cell populations. We transplanted sorted pro-B cells from $\operatorname{Pax}^{+/-} \mathrm{Ebfl}^{+/-}$mice to $\mathrm{Rag} \mathrm{I}^{-/}$mice and 6-9 weeks after transplantation nine out of ten mice had high levels of Thy 1.2 positive cells 
in spleen, and upon analysis these cells had T-specific gene expression patterns, indicating severe lineage infidelity of these cells in vivo. In three out of ten mice receiving TH cells we also found high levels of $\mathrm{CD}^{4} 3^{+} \mathrm{IgM}^{-}$pro-B cells in spleen. No progenitor cells were found in either BM or spleen.

To further confirm the lineage switch, we sorted $\mathrm{Wt}, \mathrm{Pax}^{+/}, \mathrm{EbfI}^{+/}$and $\mathrm{Pax}^{+/} \mathrm{EbfI}^{+/}$ pro-B cells and cultured them with OP9Delta stroma, promoting $\mathrm{T}$ cell development. Notch receptors are activated upon contact with Notch ligand like Delta1, after which the Notchmolecule will undergo proteolytic cleavage which releases an intracellular signaling component called intracellular notch (ICN). The $\mathrm{TH} \mathrm{CD} 19^{+}$cells were able to develop into CD19-Thy $1.2^{+}$cells expressing $\mathrm{T}$ lineage genes also in vitro. We also showed that this conversion was dependent on activation of the Notch-pathway by adding gamma secretase inhibitor DAPT which inhibits Notch signaling and release of ICN. In an in vitro time study, $\mathrm{CD}_{1}{ }^{+}$cells would start to coordinately express also Thy1.2, and after 18 days most cells were only expressing Thy 1.2 with or without CD3. By performing qPCR at each time point we detected up regulation of $\mathrm{T}$ lineage associated genes at the same time as up regulation of the $\mathrm{T}$ lineage surface markers took place. Since we saw that some of the Ragl ${ }^{-/}$animals transplanted with $\mathrm{Pax}^{+/-} \mathrm{Ebf1}^{+/}$pro-B cells had indications of disease, we wanted to study the in vivo transformation of these cells. We maintained mice for up to 40 weeks, and found that over $50 \%$ of $\mathrm{Pax}^{+/-} \mathrm{Ebfl}^{+/}$mice developed spontaneous pro-B (CD19 ${ }^{+} \mathrm{CD} 43^{+} \mathrm{IgM}^{-}$) leukemia at approximately 30 weeks of age. The corresponding number for $E b f 1^{+-}$mice was $6 \%$, and no sick animals were present in the $W t$ or $\operatorname{Pax}^{+/-}$groups. Diseased mice developed dramatically enlarged lymph nodes and when analyzing the cellular content of these, they were found to consist mainly of $\mathrm{CD} 19^{+} \mathrm{CD} 43^{+}$pro-B cells. The pro-B cells expressed normal levels of $\mathrm{B}$ lineage associated genes and thus had most likely not inactivated any second alleles. Gene expression micro array analysis of eight individual tumors identified some genes commonly down-regulated but also many genes that were differently expressed in the tumors.

To study the malignant properties of these tumor cells, we transplanted $\mathrm{CD} 19^{+} \mathrm{CD} 43^{+}$cells from three separate lymph nodes, and recipient mice fell ill after approximately three weeks. Most of the transplanted mice displayed swollen lymph nodes that contained CD $19^{+} \mathrm{CD} 43^{+}$ cells of donor origin, with a cell composition similar to the primary tumors. To study if the tumor cells, like their untransformed progenitors, could be diverted into the T-cell pathway, we simulated the Notch response by transduction of lymph node cells from two sick animals with a retrovirus encoding constitutively active Notch (ICN), or a control virus, expanded them in vitro, and transplanted these cells to host mice. When analyzing the spleen of these 
mice, we found that the control transplanted mice contained only $\mathrm{CD} 19^{+}$cells and had maintained lineage integrity, while the ICN-transformed cells however contained highly varying levels of $\mathrm{CD} 19^{+}$cells and also Thy $1.2^{+} \mathrm{CD}^{+}$cells of donor origin.

\section{Discussion and conclusions, paper V (manuscript)}

Data in this manuscript stress the importance of the transcription factor dose in normal as well as in malignant lymphocyte development. We are particularly interested in dosedependency in the context of malignancy where complete lack of a factor is seldom the case, but instead mono-allelic deletions are common (Mullighan et al., 2007). Many previous studies have focused on the result of a "knock-out" phenotype, and by these means identified genes crucial for development of one or the other lineage. There is however another aspect in the effect of reduced dose as opposed to a factor being completely absent.

In this study we have shown that simply a reduced dose of TFs required for proper B cell development will make the cells prone to malignant transformation. We have also demonstrated that we can take committed B cells and turn these into $\mathrm{T}$ cells in vitro by no further action than the signaling via Notch-receptor. Previous studies have indeed shown the ability of committed cells to regress and take on other lineage fates as a result of TF deficiency, for example $\operatorname{Pax} 5^{-/}$cells that upon dedifferentiation to a progenitor stage could restore a $\mathrm{T}$ cell population in the thymus (Cobaleda et al., 2007). The interpretation of this data is however ambiguous since these transplantation assays were performed on a Bcl2expressing background, making results of Pax5-deficiency unclear. Notch1 has been suggested to regulate $E b f l$, potentially at a posttranslational level. Our finding that we could transform $\mathrm{CD}_{19}{ }^{+} \mathrm{CD} 43^{+}$leukemic B-lineage cells into T-cells upon over expression of ICN was of particular interest. In normal function, ICN will upon association with transcription factor CSL change the function of CSL from a repressor of genes to an activator of genes. Analysis of previously published chip-seq data (Revilla et al., 2012) demonstrate that there are binding sites for both Pax 5 and EBF1 about $10 \mathrm{~kb}$ upstream of Notch1 and this site could potentially be an enhancer based on the presence of $\mathrm{H} 3 \mathrm{~K} 4 \mathrm{me} 1$ and $\mathrm{H} 3 \mathrm{~K} 4 \mathrm{me} 2$, which are typical enhancer methylation marks. We further wish to evaluate if EBF1 and/or Pax5 might is involved in modulating the binding of CSL to its regulatory elements, a function that would be disturbed in a TH with low Pax5 and EBF1 levels.

The results presented in paper $\mathrm{V}$ are exciting; however we further need to study the mechanism behind the malignancy in these mice. Microarray and qPCR data have shown us that the B cell gene programs in these cells are stable however the tumors up regulate genes 
present in progenitors as well as survival genes. What we do not know as of yet is if there is a "key" lesion common for all the tumors, since they are quite heterogeneous. Not all TH mice will develop tumors within 40 weeks, and that raises the question of a "third-hit" hypothesis. We also do not know when in development these genetic lesions occur. Are they present already in the growing fetus, or are they acquired during the lifetime of the mouse? Does it have significant meaning that the TH mice develop disease at approximately the same age? Is gender a factor? In this relatively small dataset, there is a skewing for the development of tumors in female mice, and moreover, the female mice are significantly younger at the onset of disease than the male mice. Further studies to unravel the specific molecular mechanisms behind the plasticity of $\mathrm{Pax}^{+/} \mathrm{Ebfl}^{+/}$cells are underway. 


\section{OVERALL CONCLUSIONS}

The aim of this thesis has been to study the effect of external signaling factors as well as transcription factors in both normal hematopoietic development and disease. In paper I and in paper II we focus on cytokines Flt3L and IL7, and their effect on progenitor B cells with regard to proliferation and differentiation. In paper III, IV and V (manuscript) the focus shifts toward the dose related functions of key transcription factors (Pax5, EBF1 and E2A) in both normal and hematopoietic development and disease.

We have clarified the need of simultaneous signaling, as opposed to sequential, of both Flt3-receptor and IL7R in the CLP for expansion of this population. Further, IL7 is essential for up-regulation of Ly6D, and signaling via IL7R is crucial for further commitment towards the $\mathrm{B}$ cell lineage. Proper expansion of progenitor populations is essential for the regeneration and population of the entire hematopoietic system. We have also contributed to the general knowledge of the importance of major B-lineage transcription factors, not only on phenotypic level, but also particularly the functional outcome in cells with reduced TF dose. By including the Ly6D surface marker in staining and sorting procedures, and performing both in vivo and in vitro analysis we have added to the knowledge about the lineage related functions of this marker. Our data support earlier raised questions regarding the traditionally defined CLP population as harboring a mix of lineage-biased and restricted cell types.

We have developed a murine model where B cell malignancies arise spontaneously in about $50 \%$ of the animals. With continued to studies of this model we aim to elucidate the molecular function behind the development of these malignancies. We have reason to believe that the dose of key transcription factors and events downstream of, but independent of Notchl gene expression per se are critical for B versus $\mathrm{T}$ cell development, and we have shown this both in $\operatorname{Pax5}^{-/}$and $\operatorname{Pax}^{+/-} \mathrm{Ebf1}^{+/}$cells. Genetic alterations in Pax5, EBFI and TCF3 (E2A) are common in certain types of human lymphocyte neoplasia, and by further research we hope to contribute to the understanding of the involvement of improperly regulated transcription factor networks and the development of disease. 


\section{REFERENCES}

Adolfsson, J., Borge, O.J., Bryder, D., Theilgaard-Monch, K., Astrand-Grundstrom, I., Sitnicka, E., Sasaki, Y., and Jacobsen, S.E. (2001). Upregulation of Flt3 expression within the bone marrow Lin()Scal $(+)$ c-kit(+) stem cell compartment is accompanied by loss of self-renewal capacity. Immunity $15,659-669$.

Adolfsson, J., Mansson, R., Buza-Vidas, N., Hultquist, A., Liuba, K., Jensen, C.T., Bryder, D., Yang, L., Borge, O.J., Thoren, L.A., et al. (2005). Identification of Flt3+ lympho-myeloid stem cells lacking erythro-megakaryocytic potential a revised road map for adult blood lineage commitment. Cell 121, 295-306.

Akerblad, P., Lind, U., Liberg, D., Bamberg, K., and Sigvardsson, M. (2002). Early B-cell factor $(\mathrm{O} / \mathrm{E}-1)$ is a promoter of adipogenesis and involved in control of genes important for terminal adipocyte differentiation. Molecular and cellular biology 22, 8015-8025.

Anderson, K., Rusterholz, C., Mansson, R., Jensen, C.T., Bacos, K., Zandi, S., Sasaki, Y., Nerlov, C., Sigvardsson, M., and Jacobsen, S.E. (2007). Ectopic expression of PAX5 promotes maintenance of biphenotypic myeloid progenitors coexpressing myeloid and B-cell lineage-associated genes. Blood $109,3697-3705$.

Arinobu, Y., Mizuno, S., Chong, Y., Shigematsu, H., Iino, T., Iwasaki, H., Graf, T., Mayfield, R., Chan, S., Kastner, P., et al. (2007). Reciprocal activation of GATA-1 and PU.1 marks initial specification of hematopoietic stem cells into myeloerythroid and myelolymphoid lineages. Cell stem cell $1,416-427$.

Arranz, L., Herrera-Merchan, A., Ligos, J.M., de Molina, A., Dominguez, O., and Gonzalez, S. (2012). Bmil is critical to prevent Ikaros-mediated lymphoid priming in hematopoietic stem cells. Cell Cycle 11, 65-78.

Bain, G., Maandag, E.C., Izon, D.J., Amsen, D., Kruisbeek, A.M., Weintraub, B.C., Krop, I., Schlissel, M.S., Feeney, A.J., van Roon, M., et al. (1994). E2A proteins are required for proper B cell development and initiation of immunoglobulin gene rearrangements. Cell 79, 885-892.

Bain, G., Robanus Maandag, E.C., te Riele, H.P., Feeney, A.J., Sheehy, A., Schlissel, M., Shinton, S.A., Hardy, R.R., and Murre, C. (1997). Both E12 and E47 allow commitment to the B cell lineage. Immunity $6,145-154$.

Beck, K., Peak, M.M., Ota, T., Nemazee, D., and Murre, C. (2009). Distinct roles for E12 and E47 in $B$ cell specification and the sequential rearrangement of immunoglobulin light chain loci. The Journal of experimental medicine 206, 2271-2284.

Bell, J.J., and Bhandoola, A. (2008). The earliest thymic progenitors for T cells possess myeloid lineage potential. Nature 452, 764-767.

Benezra, R. (1994). An intermolecular disulfide bond stabilizes E2A homodimers and is required for DNA binding at physiological temperatures. Cell 79, 1057-1067.

Benezra, R., Davis, R.L., Lockshon, D., Turner, D.L., and Weintraub, H. (1990). The protein Id: a negative regulator of helix-loop-helix DNA binding proteins. Cell 61, 49-59.

Berkes, C.A., and Tapscott, S.J. (2005). MyoD and the transcriptional control of myogenesis. Semin Cell Dev Biol 16, 585-595. 
Blake, J.A., and Ziman, M.R. (2014). Pax genes: regulators of lineage specification and progenitor cell maintenance. Development 141, 737-751.

Borghesi, L., Hsu, L.Y., Miller, J.P., Anderson, M., Herzenberg, L., Schlissel, M.S., Allman, D., and Gerstein, R.M. (2004). B lineage-specific regulation of V(D)J recombinase activity is established in common lymphoid progenitors. J Exp Med 199, 491-502.

Brown, M., and Wittwer, C. (2000). Flow cytometry: principles and clinical applications in hematology. Clin Chem 46, 1221-1229.

Campo, E., Swerdlow, S.H., Harris, N.L., Pileri, S., Stein, H., and Jaffe, E.S. (2011). The 2008 WHO classification of lymphoid neoplasms and beyond: evolving concepts and practical applications. Blood $117,5019-5032$.

Carotta, S., Dakic, A., D'Amico, A., Pang, S.H., Greig, K.T., Nutt, S.L., and Wu, L. (2010). The transcription factor PU.1 controls dendritic cell development and Flt3 cytokine receptor expression in a dose-dependent manner. Immunity 32, 628-641.

Carvalho, T.L., Mota-Santos, T., Cumano, A., Demengeot, J., and Vieira, P. (2001). Arrested B lymphopoiesis and persistence of activated B cells in adult interleukin 7(-/)- mice. J Exp Med 194, 1141-1150.

Casolari, D.A., Makri, M., Yoshida, C., Muto, A., Igarashi, K., and Melo, J.V. (2013). Transcriptional suppression of BACH2 by the Bcr-Abl oncoprotein is mediated by PAX5. Leukemia 27, 409-415.

Cobaleda, C., Jochum, W., and Busslinger, M. (2007). Conversion of mature B cells into T cells by dedifferentiation to uncommitted progenitors. Nature 449, 473-477.

Cui, K., Zang, C., Roh, T.Y., Schones, D.E., Childs, R.W., Peng, W., and Zhao, K. (2009). Chromatin signatures in multipotent human hematopoietic stem cells indicate the fate of bivalent genes during differentiation. Cell stem cell 4, 80-93.

Czerny, T., Schaffner, G., and Busslinger, M. (1993). DNA sequence recognition by Pax proteins: bipartite structure of the paired domain and its binding site. Genes \& development 7, 2048-2061.

Dakic, A., Metcalf, D., Di Rago, L., Mifsud, S., Wu, L., and Nutt, S.L. (2005). PU.1 regulates the commitment of adult hematopoietic progenitors and restricts granulopoiesis. The Journal of experimental medicine 201, 1487-1502.

DeKoter, R.P., Lee, H.J., and Singh, H. (2002). PU.1 regulates expression of the interleukin-7 receptor in lymphoid progenitors. Immunity 16, 297-309.

DeKoter, R.P., and Singh, H. (2000). Regulation of B lymphocyte and macrophage development by graded expression of PU.1. Science 288, 1439-1441.

Den Boer, M.L., van Slegtenhorst, M., De Menezes, R.X., Cheok, M.H., Buijs-Gladdines, J.G., Peters, S.T., Van Zutven, L.J., Beverloo, H.B., Van der Spek, P.J., Escherich, G., et al. (2009). A subtype of childhood acute lymphoblastic leukaemia with poor treatment outcome: a genome-wide classification study. Lancet Oncol 10, 125-134.

Dengler, H.S., Baracho, G.V., Omori, S.A., Bruckner, S., Arden, K.C., Castrillon, D.H., DePinho, R.A., and Rickert, R.C. (2008). Distinct functions for the transcription factor Foxol at various stages of B cell differentiation. Nat Immunol 9, 1388-1398. 
Dias, S., Mansson, R., Gurbuxani, S., Sigvardsson, M., and Kee, B.L. (2008). E2A proteins promote development of lymphoid-primed multipotent progenitors. Immunity 29, 217-227.

Dias, S., Silva, H., Jr., Cumano, A., and Vieira, P. (2005). Interleukin-7 is necessary to maintain the B cell potential in common lymphoid progenitors. J Exp Med 201, 971-979.

Druker, B.J., Talpaz, M., Resta, D.J., Peng, B., Buchdunger, E., Ford, J.M., Lydon, N.B., Kantarjian, H., Capdeville, R., Ohno-Jones, S., et al. (2001). Efficacy and safety of a specific inhibitor of the BCR-ABL tyrosine kinase in chronic myeloid leukemia. The New England journal of medicine 344, 1031-1037.

Druker, B.J., Tamura, S., Buchdunger, E., Ohno, S., Segal, G.M., Fanning, S., Zimmermann, J., and Lydon, N.B. (1996). Effects of a selective inhibitor of the Abl tyrosine kinase on the growth of BcrAbl positive cells. Nat Med 2, 561-566.

Eberhard, D., and Busslinger, M. (1999). The partial homeodomain of the transcription factor Pax-5 (BSAP) is an interaction motif for the retinoblastoma and TATA-binding proteins. Cancer research 59, 1716s-1724s; discussion 1724s-1725s.

Ephrussi, A., Church, G.M., Tonegawa, S., and Gilbert, W. (1985). B lineage--specific interactions of an immunoglobulin enhancer with cellular factors in vivo. Science 227, 134-140.

Erlandsson, L., Licence, S., Gaspal, F., Lane, P., Corcoran, A.E., and Martensson, I.L. (2005). Both the pre-BCR and the IL-7Ralpha are essential for expansion at the pre-BII cell stage in vivo. European journal of immunology 35, 1969-1976.

Feldhaus, A.L., Mbangkollo, D., Arvin, K.L., Klug, C.A., and Singh, H. (1992). BLyF, a novel celltype- and stage-specific regulator of the B-lymphocyte gene mb-1. Molecular and cellular biology 12 , 1126-1133.

Fields, S., Ternyak, K., Gao, H., Ostraat, R., Akerlund, J., and Hagman, J. (2008). The 'zinc knuckle' motif of Early B cell Factor is required for transcriptional activation of B cell-specific genes. Molecular immunology 45, 3786-3796.

Fleming, H.E., and Paige, C.J. (2001). Pre-B cell receptor signaling mediates selective response to IL7 at the pro-B to pre-B cell transition via an ERK/MAP kinase-dependent pathway. Immunity 15 , $521-531$

Forsberg, E.C., Serwold, T., Kogan, S., Weissman, I.L., and Passegue, E. (2006). New evidence supporting megakaryocyte-erythrocyte potential of flk $2 /$ flt $3+$ multipotent hematopoietic progenitors. Cell 126, 415-426.

Fuxa, M., and Busslinger, M. (2007). Reporter gene insertions reveal a strictly B lymphoid-specific expression pattern of Pax5 in support of its B cell identity function. J Immunol 178, 8222-8228.

Garel, S., Marin, F., Grosschedl, R., and Charnay, P. (1999). Ebfl controls early cell differentiation in the embryonic striatum. Development 126, 5285-5294.

Garvie, C.W., Hagman, J., and Wolberger, C. (2001). Structural studies of Ets-1/Pax5 complex formation on DNA. Mol Cell 8, 1267-1276.

Gekas, C., Dieterlen-Lievre, F., Orkin, S.H., and Mikkola, H.K. (2005). The placenta is a niche for hematopoietic stem cells. Developmental cell 8, 365-375. 
Georgiades, P., Ogilvy, S., Duval, H., Licence, D.R., Charnock-Jones, D.S., Smith, S.K., and Print, C.G. (2002). VavCre transgenic mice: a tool for mutagenesis in hematopoietic and endothelial lineages. Genesis 34, 251-256.

Georgopoulos, K., Bigby, M., Wang, J.H., Molnar, A., Wu, P., Winandy, S., and Sharpe, A. (1994). The Ikaros gene is required for the development of all lymphoid lineages. Cell 79, 143-156.

Goetz, C.A., Harmon, I.R., O'Neil, J.J., Burchill, M.A., and Farrar, M.A. (2004). STAT5 activation underlies IL7 receptor-dependent B cell development. J Immunol 172, 4770-4778.

Grawunder, U., Leu, T.M., Schatz, D.G., Werner, A., Rolink, A.G., Melchers, F., and Winkler, T.H. (1995). Down-regulation of RAG1 and RAG2 gene expression in preB cells after functional immunoglobulin heavy chain rearrangement. Immunity 3, 601-608.

Gyory, I., Boller, S., Nechanitzky, R., Mandel, E., Pott, S., Liu, E., and Grosschedl, R. (2012). Transcription factor Ebf1 regulates differentiation stage-specific signaling, proliferation, and survival of B cells. Genes \& development 26, 668-682.

Hagman, J., Gutch, M.J., Lin, H., and Grosschedl, R. (1995). EBF contains a novel zinc coordination motif and multiple dimerization and transcriptional activation domains. The EMBO journal 14, 29072916.

Hagman, J., Travis, A., and Grosschedl, R. (1991). A novel lineage-specific nuclear factor regulates mb-1 gene transcription at the early stages of B cell differentiation. EMBO J 10, 3409-3417.

Harder, L., Eschenburg, G., Zech, A., Kriebitzsch, N., Otto, B., Streichert, T., Behlich, A.S., Dierck, K., Klingler, B., Hansen, A., et al. (2013). Aberrant ZNF423 impedes B cell differentiation and is linked to adverse outcome of ETV6-RUNX1 negative B precursor acute lymphoblastic leukemia. The Journal of experimental medicine 210, 2289-2304.

Hardy, R.R., Carmack, C.E., Shinton, S.A., Kemp, J.D., and Hayakawa, K. (1991). Resolution and characterization of pro-B and pre-pro-B cell stages in normal mouse bone marrow. J Exp Med 173, 1213-1225.

Heavey, B., Charalambous, C., Cobaleda, C., and Busslinger, M. (2003). Myeloid lineage switch of Pax5 mutant but not wild-type B cell progenitors by C/EBPalpha and GATA factors. The EMBO journal 22, 3887-3897.

Heltemes-Harris, L.M., Willette, M.J., Ramsey, L.B., Qiu, Y.H., Neeley, E.S., Zhang, N., Thomas, D.A., Koeuth, T., Baechler, E.C., Kornblau, S.M., et al. (2011). Ebf1 or Pax5 haploinsufficiency synergizes with STAT5 activation to initiate acute lymphoblastic leukemia. J Exp Med 208, 11351149 .

Hesslein, D.G., Fretz, J.A., Xi, Y., Nelson, T., Zhou, S., Lorenzo, J.A., Schatz, D.G., and Horowitz, M.C. (2009). Ebf1-dependent control of the osteoblast and adipocyte lineages. Bone 44, 537-546.

Hoflinger, S., Kesavan, K., Fuxa, M., Hutter, C., Heavey, B., Radtke, F., and Busslinger, M. (2004). Analysis of Notch1 function by in vitro T cell differentiation of Pax 5 mutant lymphoid progenitors. Journal of immunology 173, 3935-3944.

Holmes, M.L., Carotta, S., Corcoran, L.M., and Nutt, S.L. (2006). Repression of Flt3 by Pax5 is crucial for B-cell lineage commitment. Genes Dev 20, 933-938. 
Hsu, L.Y., Lauring, J., Liang, H.E., Greenbaum, S., Cado, D., Zhuang, Y., and Schlissel, M.S. (2003). A conserved transcriptional enhancer regulates RAG gene expression in developing B cells. Immunity $19,105-117$.

Hsu, P.D., Lander, E.S., and Zhang, F. (2014). Development and applications of CRISPR-Cas9 for genome engineering. Cell 157, 1262-1278.

Hu, M., Krause, D., Greaves, M., Sharkis, S., Dexter, M., Heyworth, C., and Enver, T. (1997). Multilineage gene expression precedes commitment in the hemopoietic system. Genes Dev 11, $774-$ 785 .

Hyndman, B.D., Thompson, P., Bayly, R., Cote, G.P., and LeBrun, D.P. (2012). E2A proteins enhance the histone acetyltransferase activity of the transcriptional co-activators CBP and p300. Biochimica et biophysica acta 1819, 446-453.

Iacobucci, I., Storlazzi, C.T., Cilloni, D., Lonetti, A., Ottaviani, E., Soverini, S., Astolfi, A., Chiaretti, S., Vitale, A., Messa, F., et al. (2009). Identification and molecular characterization of recurrent genomic deletions on $7 \mathrm{p} 12$ in the IKZF1 gene in a large cohort of BCR-ABL1-positive acute lymphoblastic leukemia patients: on behalf of Gruppo Italiano Malattie Ematologiche dell'Adulto Acute Leukemia Working Party (GIMEMA AL WP). Blood 114, 2159-2167.

Igarashi, H., Gregory, S.C., Yokota, T., Sakaguchi, N., and Kincade, P.W. (2002). Transcription from the RAG1 locus marks the earliest lymphocyte progenitors in bone marrow. Immunity 17, 117-130.

Inaba, H., Greaves, M., and Mullighan, C.G. (2013). Acute lymphoblastic leukaemia. Lancet 381, 1943-1955.

Inlay, M.A., Bhattacharya, D., Sahoo, D., Serwold, T., Seita, J., Karsunky, H., Plevritis, S.K., Dill, D.L., and Weissman, I.L. (2009). Ly6d marks the earliest stage of B-cell specification and identifies the branchpoint between B-cell and T-cell development. Genes Dev 23, 2376-2381.

Itoh-Nakadai, A., Hikota, R., Muto, A., Kometani, K., Watanabe-Matsui, M., Sato, Y., Kobayashi, M., Nakamura, A., Miura, Y., Yano, Y., et al. (2014). The transcription repressors Bach2 and Bach1 promote B cell development by repressing the myeloid program. Nature immunology.

Iwasaki, H., Somoza, C., Shigematsu, H., Duprez, E.A., Iwasaki-Arai, J., Mizuno, S., Arinobu, Y., Geary, K., Zhang, P., Dayaram, T., et al. (2005). Distinctive and indispensable roles of PU.1 in maintenance of hematopoietic stem cells and their differentiation. Blood 106, 1590-1600.

Jensen, C.T., Boiers, C., Kharazi, S., Lubking, A., Ryden, T., Sigvardsson, M., Sitnicka, E., and Jacobsen, S.E. (2008). Permissive roles of hematopoietin and cytokine tyrosine kinase receptors in early T-cell development. Blood 111, 2083-2090.

Jeong, M., and Goodell, M.A. (2014). New answers to old questions from genome-wide maps of DNA methylation in hematopoietic cells. Experimental hematology 42, 609-617.

Johansson, U., and Macey, M. (2011). Pitfalls in the use of multicolour flow cytometry in haematology. J Clin Pathol 64, 561-563.

Karsunky, H., Inlay, M.A., Serwold, T., Bhattacharya, D., and Weissman, I.L. (2008). Flk2+ common lymphoid progenitors possess equivalent differentiation potential for the $\mathrm{B}$ and $\mathrm{T}$ lineages. Blood 111, $5562-5570$.

Keenan, R.A., De Riva, A., Corleis, B., Hepburn, L., Licence, S., Winkler, T.H., and Martensson, I.L. (2008). Censoring of autoreactive B cell development by the pre-B cell receptor. Science 321, 696699 . 
Kiel, M.J., Yilmaz, O.H., Iwashita, T., Terhorst, C., and Morrison, S.J. (2005). SLAM family receptors distinguish hematopoietic stem and progenitor cells and reveal endothelial niches for stem cells. Cell 121,1109-1121.

Kikuchi, K., Kasai, H., Watanabe, A., Lai, A.Y., and Kondo, M. (2008). IL-7 specifies B cell fate at the common lymphoid progenitor to pre-proB transition stage by maintaining early B cell factor expression. J Immunol 181, 383-392.

Kikuchi, K., Lai, A.Y., Hsu, C.L., and Kondo, M. (2005). IL-7 receptor signaling is necessary for stage transition in adult B cell development through up-regulation of EBF. J Exp Med 201, 11971203.

Kodama, H., Nose, M., Niida, S., and Nishikawa, S. (1994). Involvement of the c-kit receptor in the adhesion of hematopoietic stem cells to stromal cells. Experimental hematology 22, 979-984.

Kondo, M., Akashi, K., Domen, J., Sugamura, K., and Weissman, I.L. (1997a). Bcl-2 rescues T lymphopoiesis, but not B or NK cell development, in common gamma chain-deficient mice. Immunity 7, 155-162.

Kondo, M., Weissman, I.L., and Akashi, K. (1997b). Identification of clonogenic common lymphoid progenitors in mouse bone marrow. Cell 91, 661-672.

Kozmik, Z., Wang, S., Dorfler, P., Adams, B., and Busslinger, M. (1992). The promoter of the CD19 gene is a target for the B-cell-specific transcription factor BSAP. Molecular and cellular biology 12, $2662-2672$.

Kuiper, R.P., Schoenmakers, E.F., van Reijmersdal, S.V., Hehir-Kwa, J.Y., van Kessel, A.G., van Leeuwen, F.N., and Hoogerbrugge, P.M. (2007). High-resolution genomic profiling of childhood ALL reveals novel recurrent genetic lesions affecting pathways involved in lymphocyte differentiation and cell cycle progression. Leukemia : official journal of the Leukemia Society of America, Leukemia Research Fund, UK 21, 1258-1266.

Lassar, A.B., Davis, R.L., Wright, W.E., Kadesch, T., Murre, C., Voronova, A., Baltimore, D., and Weintraub, H. (1991). Functional activity of myogenic HLH proteins requires hetero-oligomerization with E12/E47-like proteins in vivo. Cell 66, 305-315.

le Coutre, P., Mologni, L., Cleris, L., Marchesi, E., Buchdunger, E., Giardini, R., Formelli, F., and Gambacorti-Passerini, C. (1999). In vivo eradication of human BCR/ABL-positive leukemia cells with an ABL kinase inhibitor. J Natl Cancer Inst 91, 163-168.

Lechner, M.S., and Dressler, G.R. (1996). Mapping of Pax-2 transcription activation domains. The Journal of biological chemistry 271, 21088-21093.

Levine, M., and Tjian, R. (2003). Transcription regulation and animal diversity. Nature 424, 147-151.

Li, Y.S., Hayakawa, K., and Hardy, R.R. (1993). The regulated expression of B lineage associated genes during B cell differentiation in bone marrow and fetal liver. The Journal of experimental medicine 178, 951-960.

Li, Y.S., Wasserman, R., Hayakawa, K., and Hardy, R.R. (1996). Identification of the earliest B lineage stage in mouse bone marrow. Immunity 5, 527-535.

Lin, H., and Grosschedl, R. (1995). Failure of B-cell differentiation in mice lacking the transcription factor EBF. Nature 376, 263-267. 
Lin, Y.C., Jhunjhunwala, S., Benner, C., Heinz, S., Welinder, E., Mansson, R., Sigvardsson, M., Hagman, J., Espinoza, C.A., Dutkowski, J., et al. (2010). A global network of transcription factors, involving E2A, EBF1 and Foxo1, that orchestrates B cell fate. Nat Immunol 11, 635-643.

Liu, G.J., Cimmino, L., Jude, J.G., Hu, Y., Witkowski, M.T., McKenzie, M.D., Kartal-Kaess, M., Best, S.A., Tuohey, L., Liao, Y., et al. (2014). Pax5 loss imposes a reversible differentiation block in B-progenitor acute lymphoblastic leukemia. Genes \& development 28, 1337-1350.

Liu, P., Keller, J.R., Ortiz, M., Tessarollo, L., Rachel, R.A., Nakamura, T., Jenkins, N.A., and Copeland, N.G. (2003). Bcl11a is essential for normal lymphoid development. Nat Immunol 4, 525532.

Luc, S., Luis, T.C., Boukarabila, H., Macaulay, I.C., Buza-Vidas, N., Bouriez-Jones, T., Lutteropp, M., Woll, P.S., Loughran, S.J., Mead, A.J., et al. (2012). The earliest thymic T cell progenitors sustain B cell and myeloid lineage potential. Nature immunology 13, 412-419.

Lukin, K., Fields, S., Guerrettaz, L., Straign, D., Rodriguez, V., Zandi, S., Mansson, R., Cambier, J.C., Sigvardsson, M., and Hagman, J. (2011). A dose-dependent role for EBF1 in repressing non-Bcell-specific genes. European journal of immunology 41, 1787-1793.

Mackarehtschian, K., Hardin, J.D., Moore, K.A., Boast, S., Goff, S.P., and Lemischka, I.R. (1995). Targeted disruption of the flk $2 / \mathrm{flt} 3$ gene leads to deficiencies in primitive hematopoietic progenitors. Immunity $3,147-161$.

Maeda, T., Merghoub, T., Hobbs, R.M., Dong, L., Maeda, M., Zakrzewski, J., van den Brink, M.R., Zelent, A., Shigematsu, H., Akashi, K., et al. (2007). Regulation of B versus T lymphoid lineage fate decision by the proto-oncogene LRF. Science $316,860-866$.

Malin, S., McManus, S., Cobaleda, C., Novatchkova, M., Delogu, A., Bouillet, P., Strasser, A., and Busslinger, M. (2009). Role of STAT5 in controlling cell survival and immunoglobulin gene recombination during pro-B cell development. Nat Immunol.

Mansson, R., Hultquist, A., Luc, S., Yang, L., Anderson, K., Kharazi, S., Al-Hashmi, S., Liuba, K., Thoren, L., Adolfsson, J., et al. (2007). Molecular evidence for hierarchical transcriptional lineage priming in fetal and adult stem cells and multipotent progenitors. Immunity 26, 407-419.

Mansson, R., Welinder, E., Ahsberg, J., Lin, Y.C., Benner, C., Glass, C.K., Lucas, J.S., Sigvardsson, M., and Murre, C. (2012). Positive intergenic feedback circuitry, involving EBF1 and FOXO1, orchestrates B-cell fate. Proceedings of the National Academy of Sciences of the United States of America 109, 21028-21033.

Mansson, R., Zandi, S., Anderson, K., Martensson, I.L., Jacobsen, S.E., Bryder, D., and Sigvardsson, M. (2008). B-lineage commitment prior to surface expression of B220 and CD19 on hematopoietic progenitor cells. Blood 112, 1048-1055.

Mansson, R., Zandi, S., Welinder, E., Tsapogas, P., Sakaguchi, N., Bryder, D., and Sigvardsson, M. (2009). Single cell analysis of the common lymphoid progenitor compartment reveals functional and molecular heterogeneity. Blood.

Maraskovsky, E., Peschon, J.J., McKenna, H., Teepe, M., and Strasser, A. (1998). Overexpression of Bcl-2 does not rescue impaired B lymphopoiesis in IL-7 receptor-deficient mice but can enhance survival of mature B cells. Int Immunol 10, 1367-1375. 
Marshall A. Lichtman, T.J.K., Uri Seligsohn, Kenneth Kaushansky, Josef T. Prchal (2010). Williams Hematology (The McGraw-Hill Companies).

Marshall, A.J., Fleming, H.E., Wu, G.E., and Paige, C.J. (1998). Modulation of the IL-7 doseresponse threshold during pro-B cell differentiation is dependent on pre- $\mathrm{B}$ cell receptor expression. $\mathrm{J}$ Immunol 161, 6038-6045.

Martensson, I.L., Melchers, F., and Winkler, T.H. (1997). A transgenic marker for mouse B lymphoid precursors. J Exp Med 185, 653-661.

Martinelli, G., Iacobucci, I., Storlazzi, C.T., Vignetti, M., Paoloni, F., Cilloni, D., Soverini, S., Vitale, A., Chiaretti, S., Cimino, G., et al. (2009). IKZF1 (Ikaros) deletions in BCR-ABL1-positive acute lymphoblastic leukemia are associated with short disease-free survival and high rate of cumulative incidence of relapse: a GIMEMA AL WP report. J Clin Oncol 27, 5202-5207.

McKenna, H.J., Stocking, K.L., Miller, R.E., Brasel, K., De Smedt, T., Maraskovsky, E., Maliszewski, C.R., Lynch, D.H., Smith, J., Pulendran, B., et al. (2000). Mice lacking flt3 ligand have deficient hematopoiesis affecting hematopoietic progenitor cells, dendritic cells, and natural killer cells. Blood 95, 3489-3497.

McKercher, S.R., Torbett, B.E., Anderson, K.L., Henkel, G.W., Vestal, D.J., Baribault, H., Klemsz, M., Feeney, A.J., Wu, G.E., Paige, C.J., et al. (1996). Targeted disruption of the PU.1 gene results in multiple hematopoietic abnormalities. EMBO J 15, 5647-5658.

Medvinsky, A., and Dzierzak, E. (1996). Definitive hematopoiesis is autonomously initiated by the AGM region. Cell 86, 897-906.

Mestas, J., and Hughes, C.C. (2004). Of mice and not men: differences between mouse and human immunology. J Immunol 172, 2731-2738.

Mikkola, H.K., Gekas, C., Orkin, S.H., and Dieterlen-Lievre, F. (2005). Placenta as a site for hematopoietic stem cell development. Experimental hematology 33, 1048-1054.

Mikkola, H.K., and Orkin, S.H. (2006). The journey of developing hematopoietic stem cells. Development 133, 3733-3744.

Moore, M.A., and Metcalf, D. (1970). Ontogeny of the haemopoietic system: yolk sac origin of in vivo and in vitro colony forming cells in the developing mouse embryo. Br J Haematol 18, 279-296.

Moorman, A.V., Enshaei, A., Schwab, C., Wade, R., Chilton, L., Elliott, A., Richardson, S., Hancock, J., Kinsey, S.E., Mitchell, C.D., et al. (2014). A novel integrated cytogenetic and genomic classification refines risk stratification in pediatric acute lymphoblastic leukemia. Blood 124, 1434 1444 .

Muller, A.M., Medvinsky, A., Strouboulis, J., Grosveld, F., and Dzierzak, E. (1994). Development of hematopoietic stem cell activity in the mouse embryo. Immunity 1, 291-301.

Mullighan, C.G., Goorha, S., Radtke, I., Miller, C.B., Coustan-Smith, E., Dalton, J.D., Girtman, K., Mathew, S., Ma, J., Pounds, S.B., et al. (2007). Genome-wide analysis of genetic alterations in acute lymphoblastic leukaemia. Nature 446, 758-764.

Mullighan, C.G., Miller, C.B., Radtke, I., Phillips, L.A., Dalton, J., Ma, J., White, D., Hughes, T.P., Le Beau, M.M., Pui, C.H., et al. (2008). BCR-ABL1 lymphoblastic leukaemia is characterized by the deletion of Ikaros. Nature 453, 110-114. 
Mullighan, C.G., Su, X., Zhang, J., Radtke, I., Phillips, L.A., Miller, C.B., Ma, J., Liu, W., Cheng, C., Schulman, B.A., et al. (2009). Deletion of IKZF1 and prognosis in acute lymphoblastic leukemia. The New England journal of medicine 360, 470-480.

Murre, C., McCaw, P.S., and Baltimore, D. (1989). A new DNA binding and dimerization motif in immunoglobulin enhancer binding, daughterless, MyoD, and myc proteins. Cell 56, 777-783.

Nechanitzky, R., Akbas, D., Scherer, S., Gyory, I., Hoyler, T., Ramamoorthy, S., Diefenbach, A., and Grosschedl, R. (2013). Transcription factor EBF1 is essential for the maintenance of B cell identity and prevention of alternative fates in committed cells. Nature immunology 14, 867-875.

Notta, F., Mullighan, C.G., Wang, J.C., Poeppl, A., Doulatov, S., Phillips, L.A., Ma, J., Minden, M.D., Downing, J.R., and Dick, J.E. (2011). Evolution of human BCR-ABL1 lymphoblastic leukaemia-initiating cells. Nature 469, 362-367.

Nutt, S.L., Heavey, B., Rolink, A.G., and Busslinger, M. (1999a). Commitment to the B-lymphoid lineage depends on the transcription factor Pax5. Nature 401, 556-562.

Nutt, S.L., Morrison, A.M., Dorfler, P., Rolink, A., and Busslinger, M. (1998). Identification of BSAP (Pax-5) target genes in early B-cell development by loss- and gain-of-function experiments. EMBO J 17, 2319-2333.

Nutt, S.L., Urbanek, P., Rolink, A., and Busslinger, M. (1997). Essential functions of Pax5 (BSAP) in pro-B cell development: difference between fetal and adult B lymphopoiesis and reduced V-to-DJ recombination at the IgH locus. Genes Dev 11, 476-491.

Nutt, S.L., Vambrie, S., Steinlein, P., Kozmik, Z., Rolink, A., Weith, A., and Busslinger, M. (1999b). Independent regulation of the two Pax5 alleles during B-cell development. Nat Genet 21, 390-395.

O'Riordan, M., and Grosschedl, R. (1999). Coordinate regulation of B cell differentiation by the transcription factors EBF and E2A. Immunity 11, 21-31.

Ochiai, K., Maienschein-Cline, M., Mandal, M., Triggs, J.R., Bertolino, E., Sciammas, R., Dinner, A.R., Clark, M.R., and Singh, H. (2012). A self-reinforcing regulatory network triggered by limiting IL-7 activates pre-BCR signaling and differentiation. Nature immunology 13, 300-307.

Oettinger, M.A., Schatz, D.G., Gorka, C., and Baltimore, D. (1990). RAG-1 and RAG-2, adjacent genes that synergistically activate V(D)J recombination. Science 248, 1517-1523.

Oguro, H., Yuan, J., Ichikawa, H., Ikawa, T., Yamazaki, S., Kawamoto, H., Nakauchi, H., and Iwama, A. (2010). Poised lineage specification in multipotential hematopoietic stem and progenitor cells by the polycomb protein Bmil. Cell Stem Cell 6, 279-286.

Osawa, M., Hanada, K., Hamada, H., and Nakauchi, H. (1996). Long-term lymphohematopoietic reconstitution by a single CD34-low/negative hematopoietic stem cell. Science 273, 242-245.

Palacios, R., and Steinmetz, M. (1985). Il-3-dependent mouse clones that express B-220 surface antigen, contain Ig genes in germ-line configuration, and generate B lymphocytes in vivo. Cell 41 , 727-734.

Palis, J., and Yoder, M.C. (2001). Yolk-sac hematopoiesis: the first blood cells of mouse and man. Experimental hematology 29, 927-936. 
Papathanasiou, P., Attema, J.L., Karsunky, H., Xu, J., Smale, S.T., and Weissman, I.L. (2009). Evaluation of the long-term reconstituting subset of hematopoietic stem cells with CD150. Stem cells $27,2498-2508$.

Parker, M.J., Licence, S., Erlandsson, L., Galler, G.R., Chakalova, L., Osborne, C.S., Morgan, G., Fraser, P., Jumaa, H., Winkler, T.H., et al. (2005). The pre-B-cell receptor induces silencing of VpreB and lambda5 transcription. The EMBO journal 24, 3895-3905.

Payne, K.J., and Crooks, G.M. (2007). Immune-cell lineage commitment: translation from mice to humans. Immunity 26, 674-677.

Peschon, J.J., Morrissey, P.J., Grabstein, K.H., Ramsdell, F.J., Maraskovsky, E., Gliniak, B.C., Park, L.S., Ziegler, S.F., Williams, D.E., Ware, C.B., et al. (1994). Early lymphocyte expansion is severely impaired in interleukin 7 receptor-deficient mice. J Exp Med 180, 1955-1960.

Pongubala, J.M., Northrup, D.L., Lancki, D.W., Medina, K.L., Treiber, T., Bertolino, E., Thomas, M., Grosschedl, R., Allman, D., and Singh, H. (2008). Transcription factor EBF restricts alternative lineage options and promotes B cell fate commitment independently of Pax5. Nat Immunol 9, 203 215 .

Prange, K.H., Singh, A.A., and Martens, J.H. (2014). The genome-wide molecular signature of transcription factors in leukemia. Experimental hematology 42, 637-650.

Pui, J.C., Allman, D., Xu, L., DeRocco, S., Karnell, F.G., Bakkour, S., Lee, J.Y., Kadesch, T., Hardy, R.R., Aster, J.C., et al. (1999). Notch1 expression in early lymphopoiesis influences B versus T lineage determination. Immunity 11, 299-308.

Radtke, F., Wilson, A., Stark, G., Bauer, M., van Meerwijk, J., MacDonald, H.R., and Aguet, M. (1999). Deficient T cell fate specification in mice with an induced inactivation of Notch1. Immunity $10,547-558$.

Reth, M., Petrac, E., Wiese, P., Lobel, L., and Alt, F.W. (1987). Activation of V kappa gene rearrangement in pre- $\mathrm{B}$ cells follows the expression of membrane-bound immunoglobulin heavy chains. The EMBO journal 6, 3299-3305.

Revilla, I.D.R., Bilic, I., Vilagos, B., Tagoh, H., Ebert, A., Tamir, I.M., Smeenk, L., Trupke, J., Sommer, A., Jaritz, M., et al. (2012). The B-cell identity factor Pax5 regulates distinct transcriptional programmes in early and late B lymphopoiesis. The EMBO journal 31,3130-3146.

Richter, J., Schlesner, M., Hoffmann, S., Kreuz, M., Leich, E., Burkhardt, B., Rosolowski, M., Ammerpohl, O., Wagener, R., Bernhart, S.H., et al. (2012). Recurrent mutation of the ID3 gene in Burkitt lymphoma identified by integrated genome, exome and transcriptome sequencing. Nature genetics 44, 1316-1320.

Rolink, A., Grawunder, U., Winkler, T.H., Karasuyama, H., and Melchers, F. (1994). IL-2 receptor alpha chain (CD25, TAC) expression defines a crucial stage in pre-B cell development. International immunology $6,1257-1264$.

Rolink, A., ten Boekel, E., Melchers, F., Fearon, D.T., Krop, I., and Andersson, J. (1996). A subpopulation of B220+ cells in murine bone marrow does not express CD19 and contains natural killer cell progenitors. The Journal of experimental medicine 183, 187-194.

Rolink, A.G., Nutt, S.L., Melchers, F., and Busslinger, M. (1999). Long-term in vivo reconstitution of T-cell development by Pax5-deficient B-cell progenitors. Nature 401, 603-606. 
Rosmaraki, E.E., Douagi, I., Roth, C., Colucci, F., Cumano, A., and Di Santo, J.P. (2001). Identification of committed NK cell progenitors in adult murine bone marrow. Eur J Immunol 31, 1900-1909.

Rumfelt, L.L., Zhou, Y., Rowley, B.M., Shinton, S.A., and Hardy, R.R. (2006). Lineage specification and plasticity in CD19- early B cell precursors. J Exp Med 203, 675-687.

Rundberg Nilsson, A., Bryder, D., and Pronk, C.J. (2013). Frequency determination of rare populations by flow cytometry: a hematopoietic stem cell perspective. Cytometry A 83, 721-727.

Safavi, S., Hansson, M., Karlsson, K., Biloglav, A., Johansson, B., and Paulsson, K. (2014). Novel gene targets detected by genomic profiling in a consecutive series of 126 adult acute lymphoblastic leukemia cases. Haematologica.

Sakamoto, S., Wakae, K., Anzai, Y., Murai, K., Tamaki, N., Miyazaki, M., Miyazaki, K., Romanow, W.J., Ikawa, T., Kitamura, D., et al. (2012). E2A and CBP/p300 act in synergy to promote chromatin accessibility of the immunoglobulin kappa locus. Journal of immunology 188, 5547-5560.

Sambandam, A., Maillard, I., Zediak, V.P., Xu, L., Gerstein, R.M., Aster, J.C., Pear, W.S., and Bhandoola, A. (2005). Notch signaling controls the generation and differentiation of early $\mathrm{T}$ lineage progenitors. Nature immunology 6, 663-670.

Sander, J.D., and Joung, J.K. (2014). CRISPR-Cas systems for editing, regulating and targeting genomes. Nat Biotechnol 32, 347-355.

Schatz, D.G., Oettinger, M.A., and Baltimore, D. (1989). The V(D)J recombination activating gene, RAG-1. Cell 59, 1035-1048.

Schilham, M.W., Oosterwegel, M.A., Moerer, P., Ya, J., de Boer, P.A., van de Wetering, M., Verbeek, S., Lamers, W.H., Kruisbeek, A.M., Cumano, A., et al. (1996). Defects in cardiac outflow tract formation and pro-B-lymphocyte expansion in mice lacking Sox-4. Nature 380, 711-714.

Schmitt, C.E., Lizama, C.O., and Zovein, A.C. (2014). From transplantation to transgenics: mouse models of developmental hematopoiesis. Experimental hematology 42, 707-716.

Schmitt, T.M., and Zuniga-Pflucker, J.C. (2002). Induction of T cell development from hematopoietic progenitor cells by delta-like-1 in vitro. Immunity 17, 749-756.

Schmitz, R., Young, R.M., Ceribelli, M., Jhavar, S., Xiao, W., Zhang, M., Wright, G., Shaffer, A.L., Hodson, D.J., Buras, E., et al. (2012). Burkitt lymphoma pathogenesis and therapeutic targets from structural and functional genomics. Nature 490, 116-120.

Schwarz, B.A., and Bhandoola, A. (2004). Circulating hematopoietic progenitors with T lineage potential. Nat Immunol 5, 953-960.

Scott, E.W., Simon, M.C., Anastasi, J., and Singh, H. (1994). Requirement of transcription factor PU.1 in the development of multiple hematopoietic lineages. Science 265, 1573-1577.

Seet, C.S., Brumbaugh, R.L., and Kee, B.L. (2004). Early B cell factor promotes B lymphopoiesis with reduced interleukin 7 responsiveness in the absence of E2A. J Exp Med 199, 1689-1700.

Seo, W., Ikawa, T., Kawamoto, H., and Taniuchi, I. (2012). Runx1-Cbfbeta facilitates early B lymphocyte development by regulating expression of Ebf1. The Journal of experimental medicine 209, 1255-1262. 
Shah, N.P., Tran, C., Lee, F.Y., Chen, P., Norris, D., and Sawyers, C.L. (2004). Overriding imatinib resistance with a novel ABL kinase inhibitor. Science 305, 399-401.

Shen, C.P., and Kadesch, T. (1995). B-cell-specific DNA binding by an E47 homodimer. Mol Cell Biol 15, 4518-4524.

Sigvardsson, M. (2000). Overlapping expression of early B-cell factor and basic helix-loop-helix proteins as a mechanism to dictate B-lineage-specific activity of the lambda5 promoter. Mol Cell Biol $20,3640-3654$.

Siponen, M.I., Wisniewska, M., Lehtio, L., Johansson, I., Svensson, L., Raszewski, G., Nilsson, L., Sigvardsson, M., and Berglund, H. (2010). Structural determination of functional domains in early Bcell factor (EBF) family of transcription factors reveals similarities to Rel DNA-binding proteins and a novel dimerization motif. J Biol Chem 285, 25875-25879.

Sitnicka, E., Brakebusch, C., Martensson, I.L., Svensson, M., Agace, W.W., Sigvardsson, M., BuzaVidas, N., Bryder, D., Cilio, C.M., Ahlenius, H., et al. (2003). Complementary signaling through flt3 and interleukin-7 receptor alpha is indispensable for fetal and adult B cell genesis. J Exp Med 198, 1495-1506.

Sitnicka, E., Bryder, D., Theilgaard-Monch, K., Buza-Vidas, N., Adolfsson, J., and Jacobsen, S.E. (2002). Key role of flt3 ligand in regulation of the common lymphoid progenitor but not in maintenance of the hematopoietic stem cell pool. Immunity 17, 463-472.

Sloan, S.R., Shen, C.P., McCarrick-Walmsley, R., and Kadesch, T. (1996). Phosphorylation of E47 as a potential determinant of B-cell-specific activity. Molecular and cellular biology 16, 6900-6908.

Smith, Z.D., and Meissner, A. (2013). DNA methylation: roles in mammalian development. Nat Rev Genet 14, 204-220.

Souabni, A., Cobaleda, C., Schebesta, M., and Busslinger, M. (2002). Pax5 promotes B lymphopoiesis and blocks T cell development by repressing Notch1. Immunity 17, 781-793.

Spooner, C.J., Cheng, J.X., Pujadas, E., Laslo, P., and Singh, H. (2009). A recurrent network involving the transcription factors PU.1 and Gfil orchestrates innate and adaptive immune cell fates. Immunity $31,576-586$.

Sun, X.H., and Baltimore, D. (1991). An inhibitory domain of E12 transcription factor prevents DNA binding in E12 homodimers but not in E12 heterodimers. Cell 64, 459-470.

Tagoh, H., Schebesta, A., Lefevre, P., Wilson, N., Hume, D., Busslinger, M., and Bonifer, C. (2004). Epigenetic silencing of the c-fms locus during B-lymphopoiesis occurs in discrete steps and is reversible. The EMBO journal 23, 4275-4285.

Teachenor, R., Beck, K., Wright, L.Y., Shen, Z., Briggs, S.P., and Murre, C. (2012). Biochemical and phosphoproteomic analysis of the helix-loop-helix protein E47. Molecular and cellular biology 32, 1671-1682.

Teglund, S., McKay, C., Schuetz, E., van Deursen, J.M., Stravopodis, D., Wang, D., Brown, M., Bodner, S., Grosveld, G., and Ihle, J.N. (1998). Stat5a and Stat5b proteins have essential and nonessential, or redundant, roles in cytokine responses. Cell 93, 841-850.

Travis, A., Hagman, J., Hwang, L., and Grosschedl, R. (1993). Purification of early-B-cell factor and characterization of its DNA-binding specificity. Molecular and cellular biology 13, 3392-3400. 
Treiber, N., Treiber, T., Zocher, G., and Grosschedl, R. (2010). Structure of an Ebf1:DNA complex reveals unusual DNA recognition and structural homology with Rel proteins. Genes \& development $24,2270-2275$.

Tudor, K.S., Payne, K.J., Yamashita, Y., and Kincade, P.W. (2000). Functional assessment of precursors from murine bone marrow suggests a sequence of early B lineage differentiation events. Immunity $12,335-345$.

Urbanek, P., Wang, Z.Q., Fetka, I., Wagner, E.F., and Busslinger, M. (1994). Complete block of early $\mathrm{B}$ cell differentiation and altered patterning of the posterior midbrain in mice lacking Pax5/BSAP. Cell 79, 901-912.

Waddington, C.H. (2012). The epigenotype. 1942. Int J Epidemiol 41, 10-13.

Wang, J.H., Nichogiannopoulou, A., Wu, L., Sun, L., Sharpe, A.H., Bigby, M., and Georgopoulos, K. (1996). Selective defects in the development of the fetal and adult lymphoid system in mice with an Ikaros null mutation. Immunity 5, 537-549.

Wang, M.M., and Reed, R.R. (1993). Molecular cloning of the olfactory neuronal transcription factor Olf- 1 by genetic selection in yeast. Nature $364,121-126$.

Warming, S., Liu, P., Suzuki, T., Akagi, K., Lindtner, S., Pavlakis, G.N., Jenkins, N.A., and Copeland, N.G. (2003). Evi3, a common retroviral integration site in murine B-cell lymphoma, encodes an EBFAZ-related Kruppel-like zinc finger protein. Blood 101, 1934-1940.

Weishaupt, H., Sigvardsson, M., and Attema, J.L. (2010). Epigenetic chromatin states uniquely define the developmental plasticity of murine hematopoietic stem cells. Blood 115, 247-256.

Welinder, E., Mansson, R., Mercer, E.M., Bryder, D., Sigvardsson, M., and Murre, C. (2011). The transcription factors E2A and HEB act in concert to induce the expression of FOXO1 in the common lymphoid progenitor. Proceedings of the National Academy of Sciences of the United States of America 108, 17402-17407.

Wilson, A., MacDonald, H.R., and Radtke, F. (2001). Notch 1-deficient common lymphoid precursors adopt a B cell fate in the thymus. The Journal of experimental medicine 194, 1003-1012.

von Freeden-Jeffry, U., Vieira, P., Lucian, L.A., McNeil, T., Burdach, S.E., and Murray, R. (1995). Lymphopenia in interleukin (IL)-7 gene-deleted mice identifies IL-7 as a nonredundant cytokine. J Exp Med 181, 1519-1526.

Xu, W., Rould, M.A., Jun, S., Desplan, C., and Pabo, C.O. (1995). Crystal structure of a paired domain-DNA complex at 2.5 A resolution reveals structural basis for Pax developmental mutations. Cell 80, 639-650.

Yamasaki, N., Miyazaki, K., Nagamachi, A., Koller, R., Oda, H., Miyazaki, M., Sasaki, T., Honda, Z.I., Wolff, L., Inaba, T., et al. (2010). Identification of Zfp521/ZNF521 as a cooperative gene for E2A-HLF to develop acute B-lineage leukemia. Oncogene 29, 1963-1975.

Yang, J.J., Bhojwani, D., Yang, W., Cai, X., Stocco, G., Crews, K., Wang, J., Morrison, D., Devidas, M., Hunger, S.P., et al. (2008). Genome-wide copy number profiling reveals molecular evolution from diagnosis to relapse in childhood acute lymphoblastic leukemia. Blood 112, 4178-4183.

Yao, Z., Cui, Y., Watford, W.T., Bream, J.H., Yamaoka, K., Hissong, B.D., Li, D., Durum, S.K., Jiang, Q., Bhandoola, A., et al. (2006). Stat5a/b are essential for normal lymphoid development and differentiation. Proc Natl Acad Sci U S A 103, 1000-1005. 
Yoshida, T., Ng, S.Y., Zuniga-Pflucker, J.C., and Georgopoulos, K. (2006). Early hematopoietic lineage restrictions directed by Ikaros. Nature immunology 7, 382-391.

Yu, Y., Wang, J., Khaled, W., Burke, S., Li, P., Chen, X., Yang, W., Jenkins, N.A., Copeland, N.G., Zhang, S., et al. (2012). Bcl11a is essential for lymphoid development and negatively regulates p53. The Journal of experimental medicine 209, 2467-2483.

Zandi, S., Mansson, R., Tsapogas, P., Zetterblad, J., Bryder, D., and Sigvardsson, M. (2008). EBF1 is essential for B-lineage priming and establishment of a transcription factor network in common lymphoid progenitors. J Immunol 181, 3364-3372.

Zetterblad, J., Qian, H., Zandi, S., Mansson, R., Lagergren, A., Hansson, F., Bryder, D., Paulsson, N., and Sigvardsson, M. (2010). Genomics based analysis of interactions between developing Blymphocytes and stromal cells reveal complex interactions and two-way communication. BMC Genomics 11, 108.

Zhuang, Y., Cheng, P., and Weintraub, H. (1996). B-lymphocyte development is regulated by the combined dosage of three basic helix-loop-helix genes, E2A, E2-2, and HEB. Mol Cell Biol 16, 28982905 .

Zhuang, Y., Soriano, P., and Weintraub, H. (1994). The helix-loop-helix gene E2A is required for B cell formation. Cell 79, 875-884. 



\section{Papers}

The articles associated with this thesis have been removed for copyright reasons. For more details about these see:

http://urn.kb.se/resolve?urn=urn:nbn:se:liu:diva-114273 